Original Paper http://ajol.info/index.php/ijbcs http://indexmedicus.afro.who.int

\title{
Volcanology and geochemical study of the volcanic rocks of the Bafmeng area (Mount Oku, Cameroon Volcanic Line)
}

\author{
Marie-Louise Vohnyui CHENYI ${ }^{1,2}$, David Guimollaire NKOUATHIO ${ }^{2}$, \\ Pierre WOTCHOKO ${ }^{1 *}$, Gus Djibril KOUANKAP NONO ${ }^{1}$, Itiga ZÉNON ${ }^{3}$, \\ Christian Suh GUEDJEO ${ }^{1,2}$ and Dieudonné TCHOKONA SEUWUI ${ }^{4}$ \\ ${ }^{1}$ Department of Geology, Higher Teacher Training College, University of Bamenda, Bambili, P.O. Box 39, \\ Bamenda, Cameroon. \\ ${ }^{2}$ Department of Earth Sciences, Faculty of Sciences, University of Dschang, P.O. Box 67, Dschang, Cameroon. \\ ${ }^{3}$ Institute for Geological and Mining Research (IRGM), Branch of Volcanologic and Geophysics Research \\ (ARGV), P.O. Box 4110, Yaoundé, Cameroon. \\ ${ }^{4}$ Department of Earth Sciences, Faculty of Sciences, University of Yaounde 1, P.O. Box 812, Yaounde, \\ Cameroon. \\ *Corresponding author; E-mail: pierrewotchoko@yahoo.fr
}

\begin{abstract}
Detailed volcanological and petrographic descriptions, and petrogenetic studies of lavas from Bafmeng were performed, with the aim to establish their origin, magmatic evolution, and the tectonic environment. Bafmeng area is located on the NW flank of Mount Oku, an important volcanic massif along the Cameroon Volcanic Line in Central Africa. Four types of eruptive dynamisms are successively manifested; (1) an effusive dynamism (basaltic flows); (2), an extrusive dynamism (rhyolitic and trachytic domes); (3) a basaltic explosive dynamism (Strombolian cones) and (4) hydromagmatic eruption (maar). The lavas form a sodic alkaline series with three distinctive types: ultra-basic type (basanite), an intermediate type (benmoreite and trachyte), and an acid type (rhyolite). The mineralogical composition is made up of olivine, augite, plagioclase and opaque minerals for basic lavas. Acidic lavas are made up of sanidine, quartz, clinopyroxene, opaque minerals, and aegyrine. The peridotite has as minerals; plagioclases, spinel, olivine, and pyroxene The lavas show enrichment in LREE as compared to HREE with negative anomalies in $\mathrm{Ba}, \mathrm{Eu}, \mathrm{Sr}$ in trachyte and rhyolite and a positive anomalies in $\mathrm{Nb}, \mathrm{La}, \mathrm{Zr}$, Dy. The major process responsible for the emplacement of the Bafmeng felsic lavas is partial melting of spinel-garnet rich peridotite, followed by contamination and assimilation. Mafic lavas are derived from the partial melting of the asthenospheric mantle. The tectonic context based on geochemistry indicates that, the regional development is related to within plate setting.
\end{abstract}

(C) 2017 International Formulae Group. All rights reserved.

Keywords: Cameroon Volcanic Line, Mount Oku, Bafmeng, Peridotite, Eruptive dynamism.

\section{INTRODUCTION}

The Cameroon Volcanic Line (CVL) as well as many other volcanic provinces across the African plate is characterized by associations of Tertiary to recent volcanism
(Nkouathio et al., 2008; Njonfang et al., 2011). It forms one of the major geologic lineaments of the African plate. This Volcanic Line consists of a continental part marked by a trend of horst (Manengouba, Bambouto, Bamenda 
and $\mathrm{Oku}$ ) and graben (Tombel and Mbo). The oceanic part comprises four Islands and two large seamounts (Halliday et al., 1988; Burke, 2001). Geochemically, the volcanic rocks of the CVL are almost identical in both oceanic and continental sectors especially for trace elements in basalts. This implies a related upper mantle source from somewhere above the $670 \mathrm{~km}$ transition zone (Halliday et al., 1988, 1990; Lee et al., 1994). However, some tholeiitic and transitional affinities have been described and discussed recently (Fosso et al., 2005; Kuepouo et al., 2006; Moundi et al., 2007; Ngounouno et al., 2001; Wotchoko et al., 2015).

The Bafmeng area is situated on the NW flank of Mount Oku, which is the main massif of the Oku Volcanic Group composed of Nyos, Nkambe and Babanki areas. According to Njilah (2007), the volcanic rocks of Mount Oku indicates a compositional gap between mafic and acid lava.

In this work, we performed a detailed volcanological and petrographic descriptions, and petrogenetic studies of lavas from Bafmeng, with the aim to establish their origin, magmatic evolution, and the tectonic environment. The results were compared with data from other lavas along the Cameroon Volcanic Line and mantellic poles.

\section{MATERIALS AND METHODS Geologic background}

Bafmeng area belongs to the Oku volcanic massif and is located on the NW flank of Mount Oku, (about $77.2 \mathrm{~km}$ from Mount Bamenda, and $10.8 \mathrm{~km}$ from Lake Nyos). It lies between longitude $10^{\circ} 08^{\prime} 30^{\prime \prime} \mathrm{E}$ and $10^{\circ} 16^{\prime} 30^{\prime \prime} \mathrm{E}$ and latitudes $6^{\circ} 20^{\prime} 08^{\prime \prime}$ and $6^{\circ} 26^{\prime} 30^{\prime \prime} \mathrm{N}$ (Figure 1). Mount Oku is one of the Mounts that make up the Oku Volcanic Group (OVG) alongside with Babanki, Nkambe and Nyos. Mount Oku is situated close to the intersection between the extension of the continent on the transformed fault of Patos and $\mathrm{N} 30^{\circ} \mathrm{E}$ trending structure of the CVL (Lissom, 1991). Mount Oku has the highest elevation and hosts lake Oku and the infamous lake Nyos. The Oku massif which occupies the central position along the continental sector of the trend is a complex stratovolcanic edifice approximately $90 \mathrm{~km}$ in diameter and $3011 \mathrm{~m}$ height (Njilah et al., 1991, 2007).

\section{Analytical techniques}

Sixteen thin sections of the representative rock samples were carried out in the geotech lab (Canada). The thin sections were then studied in the geology laboratories of the Universities of Dschang and Bamenda. For geochemical analysis, it was performed in the ACME laboratory, Vancouver, Canada. A total of twenty two samples were analysed, with each rock type having at least seven samples for confirmation. All the samples required pulverizing to obtain homogeneous samples. After crushing and milling, samples were split and $50-60 \mathrm{~g}$ of samples was obtained for the analysis. Whole rock analysis for major and trace elements were carried out by Inductively Coupled Plasma-Atomic Emission Spectroscopy (ICP-AES). These samples were decomposed, by lithium metaborate/lithium Tetraborate $\left(\mathrm{LiBO}_{2} / \mathrm{Li}_{2} \mathrm{O}_{4} \mathrm{O}_{7}\right)$ fusion (FUSLiO1). The resulting melt is then cooled and dissolved in $100 \mathrm{Ml}$ of $4 \%$ nitric acid $/ 2 \%$ hydrochloric acid for major elements and $4 \% \mathrm{HNO} 3 / 2 \% \mathrm{Hcl}$ for trace elements. This solution is then analyzed by ICP-AES and the results are corrected for spectral inter-element interferences. Oxide concentration is calculated from the determined elemental concentration. The analytical uncertainties vary from $0.1 \%$ to $0.04 \%$ for major elements to $0.5 \%$ for trace elements, and from 0.01 to 0.5 ppm for REE. 


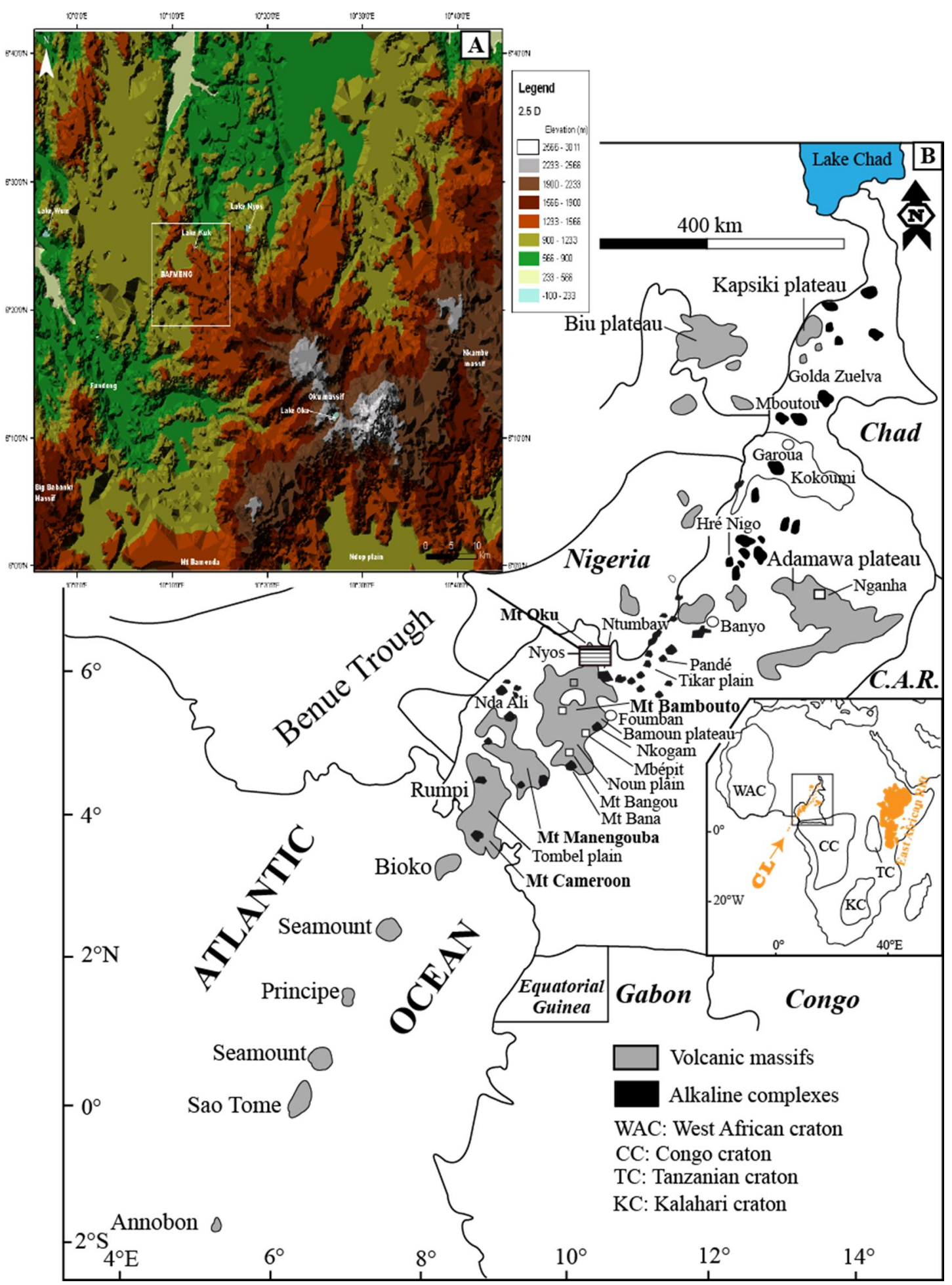

Figure 1: A-Location of the Bafmeng area (the white square mark, top left). B-location of Mount Oku along the Cameroon Volcanic Line (adapted after Halliday et al., 1988); location of seamounts after Burke (2001). Inset bottom right is after Kampunzu et Popoff (1991). 


\section{RESULTS}

\section{Volcanology}

The Bafmeng area shows four different types of dynamism: (i) Effusive dynamism, represented by the 'aa' lava flow and other lavas form a shield volcano. The 'aa' lava outcrops as blocks and boulders with size ranges of $30 \mathrm{~cm}$ to $80 \mathrm{~cm}$. This lava has estimated thickness of $70 \mathrm{~m}$ and sometimes shows columns. (ii)The Extrusive dynamism occurs as flow dome and gentle lava dome with trachytic and rhyolitic compositions and having cone or rounded shaped. A trend of the rhyolitic dome occurs forming a cumulate. (iii) The Strombolian dynamism; gives an origin of more than five tephra or scoria cones. The deposits consist of vesicular basalts or scoria bombs, ash, and cinder, with coarser and massive to coarsely bedded structures. The tephra deposits contain abundant vesicles giving the lapilli and bombs a cindery or scoraceous appearance. They are asymmetrical, have average heights of $150 \mathrm{~m}$ with slopes dipping at an angle of $10-15^{\circ}$. (iv) The hydromagmatic dynamism gives different types of deposits and depositional features. The rock fragments range in size from ash to boulders. The bombs have an average size of $35 \mathrm{~cm}$ and are usually found at the bottom of the stratigraphic column. The blocks are angular-subangular. The most conspicuous depositional feature shown by the tephra deposit is millimetre to centimetre planar layering and beddings. The maar sequence is divided into two subunits based on the dominant type of layers, stratification, grain size and structures present.

(i) Sequence one is approximately 202 $\mathrm{cm}$ thick; and dips $85^{\circ} \mathrm{E}$. It is characterized by the dominant presence of fine-grained ash, accretionary lapilli, lapilli and a mixture of both ash and lapilli (Figure 2A). Ash and lapilli forms one episode. Eight episodes occur in this sequence, intervened by a period of nondeposition indicative by the presence of a paleosoil. The presence of a paleosoil provides evidence of long repose suggesting a long eruptive duration or a relatively large store of magma beneath Nyi maar. Its layers measure 6 $\mathrm{cm}, 5 \mathrm{~cm}$ and $4 \mathrm{~cm}$ respectively from the bottom in terms of thickness. Within these layers there is a mixture of substratum. The base of this sequence is $38 \mathrm{~cm}$ thick made up of ash and lapilli. This is overlain by a $14 \mathrm{~cm}$ thick, massive, dark brown, well sorted lapilli sized and ash layer ( $7 \mathrm{~cm}$ thick), with granites and peridotite enclaves. This is again overlain by a paleosoil that is $6 \mathrm{~cm}$ thick. The middle part is made up of ash, lapilli, dominated by non-juvenile fragments which are in turn overlain by a paleosoil layer of $5 \mathrm{~cm}$. However, the accessory fragments increase upwards. The upper part is underlain by another paleosoil layer measuring $4 \mathrm{~cm}$ thick.

(ii) Sequence two begins with a marked abundance of pyroclastic breccias (bombs, scoria and blocks) with very coarse grain sizes. It shows one episode of fining upwards. The sequence grades from bombs to scoria-lapilliashy soil. It dips at $49^{\circ} \mathrm{SE}$ and has an overall thickness of $199 \mathrm{~cm}$ (Figure 2B).

\section{Petrography}

Amongst the sixteen thin sections carried out, the petrographic types in the Bafmeng area is comprised of basalts for the mafic rocks, trachyte as intermediate rocks, rhyolite as acid rock and finally mantle xenoliths as ultramafic rocks.

The mafic rocks outcrop as lava flows, bombs, scoria, tuff and lava domes. They show porphyritic, aphanitic, and scoriated texture. 
The mafic lavas are mainly euhedral containing olivine, plagioclase, pyroxene and opaque minerals (Figure 3 A, 3 B). Olivine is the dominant mineral phase for the mafic rocks and occurs both as individuals and in clusters, but subhedral in the ground mass. The plagioclases are euhedral-anhedral and have an extinction angle of $27^{\circ}-33^{\circ}$ represented by labradorite composition. The pyroxenes are also euhedral to anhedral with an inclined extinction of $42^{\circ}$ indicating clinopyroxene of augite composition.

The intermediate and acid rocks outcrop as domes. Trachyte shows a microliticporphyritic texture and the most dominant mineral phase is sanidine forming $55-66 \%$ by volume, plagioclase $(4-6 \%)$, pyroxene $(<7 \%)$ and opaque minerals $(8-10 \%)$. Olivine is also present and forms $(<2 \%)$ of the rock (Figure 3 D). Rhyolite has a porphyritic texture with phenocryst of quartz and alkaline feldspar and occurs as cumulate domes. This lava shows a microlitic-porphyritic texture with a homogenous mineralogy made up of quartz, feldspars, pyroxene and oxides in the groundmass. Sanidine constitutes $90 \%$ of the rock by volume, the aegyrine which is not well crystallised occupies (6-7\%) of the rock, and quartz occupies $(<2 \%)$ with a matrix very rich in the aegyrine (Figure 3C).

For the mantle xenoliths the texture exhibited by this peridotite is porphyroclastic texture. It has regular boundaries with slight internal strain, deformational twins and undulose extinction. This grain has subsequent shape that may attain $4 \mathrm{~mm}$ but are averagely 2 $\mathrm{mm}$. The neoblast are recrystallised grains, showing granuloblastic grain shapes. They have a curvilinear grain boundary and are devoid of deformational twins and undulose extinction. Their size is averagely $0.5 \mathrm{~mm}$. The porphyroblast are more abundant than the neoblast. Peridotite consists of a five phase assemblage of olivine, pyroxene, spinel, plagioclase and oxides. Olivine (68.69\%) occurs both as porphyroblast and neoblast. The porphyroblast attains $3 \mathrm{~mm}$, have irregular grain limits, show undulose extinction and deformational twins. It also exhibits kink bands. The neoblasts are averagely $0.5 \mathrm{~mm}$ and have curvilinear limits. Orthopyroxene (17.93\%) (hypersthene) occurs as porphyroblast, attains $4 \mathrm{~mm}$ and are strained showing deformational twins with corroded borders. The neoblasts are averagely $0.5 \mathrm{~mm}$ and are devoid of deformational twins. Clinopyroxene $(8.69 \%)$ is diopside and is found between olivine and orthopyroxene. It has an anhedral shape and averagely attains 0.5 $\mathrm{mm}$. It has corroded borders. Spinel $(2.69 \%)$ crystals are subhedral in shape and the colour is zoned. It has a brown core and dark rims. The dark rims are festooned and occur in contact with plagioclase and clinopyroxene. It is rectilinear and at times destabilized. Plagioclase $(1.77 \%)$ occurs in melt poles as microlites around destabilised spinel forming festooned borders and melt veins (Figure $3 \mathrm{E}$, F). The presence of melt poles is either from infiltration of host basalt or destabilisation of previous phases. Oxides $(0.23 \%)$ are dark in colour and exhibit an oval shape. It has an average size range of 0.5 by $0.25 \mathrm{~mm}$. Using modal compositional plot of Le Maitre, (2002), the peridotite of the study area falls within the lherzolite facies (Figure 4), with $72.07 \%$ of olivine, $18.81 \%$ of orthopyroxene and $9.12 \%$ of clinopyroxene

The various rock types helped us to come out with a geologic map of the area (Figure 5). Based on field relationship, the rhyolite seems to be younger than the trachyte, 
and basalts respectively. The older basaltic flows have thus been partly eroded before the emplacement of the rhyolitic domes in the area. The domes are also being partly weathered as it has easily dissolvable cations.

\section{Geochemistry}

\section{Major element compositions}

All the major oxides have been normalised to $100 \%$ on an anhydrous basis. Analyses are plotted on the total alkaline versus silica diagram (Le Maitre, 2002) (Figure 6). According to this diagram, all the samples have alkaline affinity. Based on whole rock major element chemical composition (1), the Bafmeng samples range in composition from basanite (more than $10 \%$ normative olivine), benmoreite $\quad\left(\mathrm{Na}_{2} \mathrm{O}-2 \geq \mathrm{K}_{2} \mathrm{O}\right)$, trachyte (normative quartz $<20 \%$ ) to rhyolite. In the $\mathrm{Na}_{2} \mathrm{O}$ versus $\mathrm{K}_{2} \mathrm{O}$ of Middlemost (1975) (Figure 7), the Bafmeng lavas plot in the Naseries and $\mathrm{K}$-series field $\left(\mathrm{Na}_{2} \mathrm{O} / \mathrm{K}_{2} \mathrm{O}=1.44\right.$ 2.08) and belongs to the under-saturated alkaline sodic series, for basic and intermediate terms but the acidic terms are fairly potassic. Concentration of major oxides such as $\mathrm{Fe}_{2} \mathrm{O}_{3}$, $\mathrm{CaO}, \mathrm{P}_{2} \mathrm{O}_{5}, \mathrm{TiO}_{2}, \mathrm{MgO}$ show a negative correlation with increase in $\mathrm{SiO}_{2}$ while $\mathrm{Na}_{2} \mathrm{O}$, $\mathrm{Al}_{2} \mathrm{O}_{3}, \mathrm{~K}_{2} \mathrm{O}$ show a positive correlation from basanite to rhyolite (Figure 8).

\section{Trace element compositions}

Trace element data for the lava of Bafmeng region are presented in Table 2. The concentrations of $\mathrm{Ni}, \mathrm{Co}, \mathrm{V}$, and $\mathrm{Cr}$ range from 14ppm-3ppm, 38ppm-1ppm, 238ppm-5ppm and $10 \mathrm{ppm}$ respectively. Figure 9 presents trace element variations against $\mathrm{SiO}_{2}$. Concentrations of $\mathrm{Ni}, \mathrm{Co}, \mathrm{V}, \mathrm{Cu}$ and $\mathrm{Sr}$ in the samples decreases with increasing $\mathrm{SiO}_{2}$, while for the incompatible elements; $\mathrm{Ba}, \mathrm{Nb}, \mathrm{Rb}, \mathrm{La}$, $\mathrm{Hf}, \mathrm{Ce}, \mathrm{Yb}, \mathrm{Zr}$ increases with increase $\mathrm{SiO}_{2}$ from basanite to rhyolite and $\mathrm{Cr}$ is linear.

A chondrite normalised REE diagrams (Figure 10) shows LREE enrichment versus HREE from basanite to rhyolite. The spectrum of trachyte and rhyolite are superimposed and are parallel with rhyolite that has a negative $\mathrm{Eu}$ anomaly. For multi-element normalised against primitive mantle (Sun and McDonough, 1989), the spectrum shows strong negative anomalies in $\mathrm{Ba}, \mathrm{Eu}, \mathrm{Sr}$ in trachyte and rhyolite and positive anomalies in $\mathrm{Nb}, \mathrm{La}, \mathrm{Nd}, \mathrm{Zr}, \mathrm{Sm}, \mathrm{Gd}, \mathrm{Hf}$, Ce and $\mathrm{Y}$ both in trachyte and rhyolite (Figure 11).

The ratios of some trace elements have distinctive values corresponding to different mantellic sources (Table 3). Such ratios; $\mathrm{Zr} / \mathrm{Nb}, \mathrm{La} / \mathrm{Nb}, \mathrm{Rb} / \mathrm{Nb}, \mathrm{Th} / \mathrm{Nb}$, and $\mathrm{Th} / \mathrm{La}$, have values higher than those of HIMU but is within EMI, EMII, close to lavas of Mount Manengouba, Mount Bamenda, Mount Bambouto Tombel plain and Mount Oku. While $\mathrm{Ba} / \mathrm{Nb}, \mathrm{Ba} / \mathrm{Th}, \mathrm{Ba} / \mathrm{La}, \mathrm{K} / \mathrm{Nb}$ are lower than the HIMU but within Mount Oku. These relations provide necessary clues on the components of the mantle source (Weaver, 1991). In this case, the relations of the lavas of Bafmeng are in conformity with those of EMI, EMII mantelic poles of OIB, suggesting that the parent magma of the lavas of Bafmeng originates from an enriched mantle source (EMI and EMII). 
A

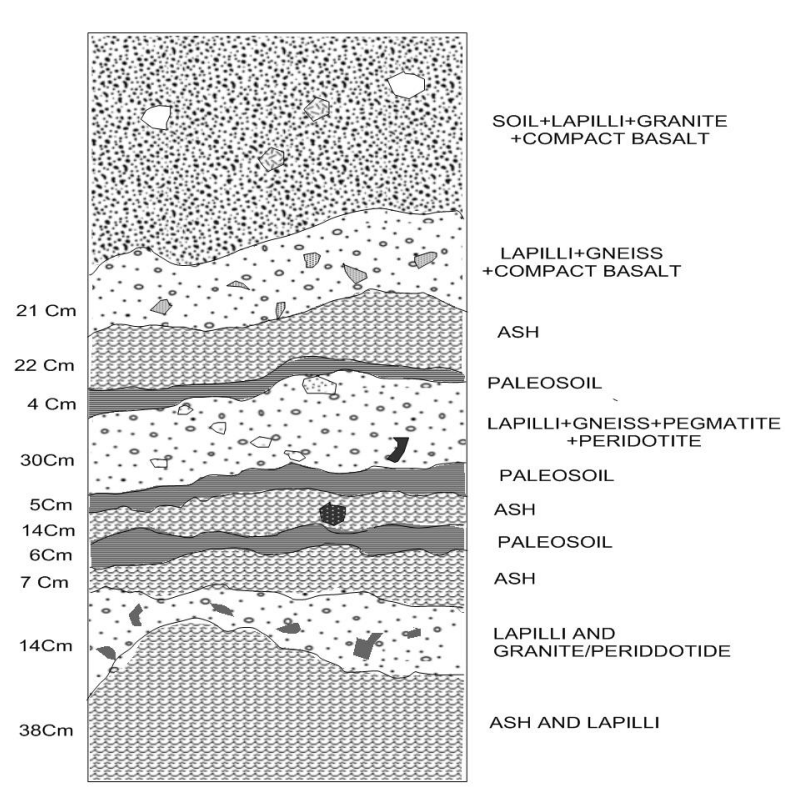

B

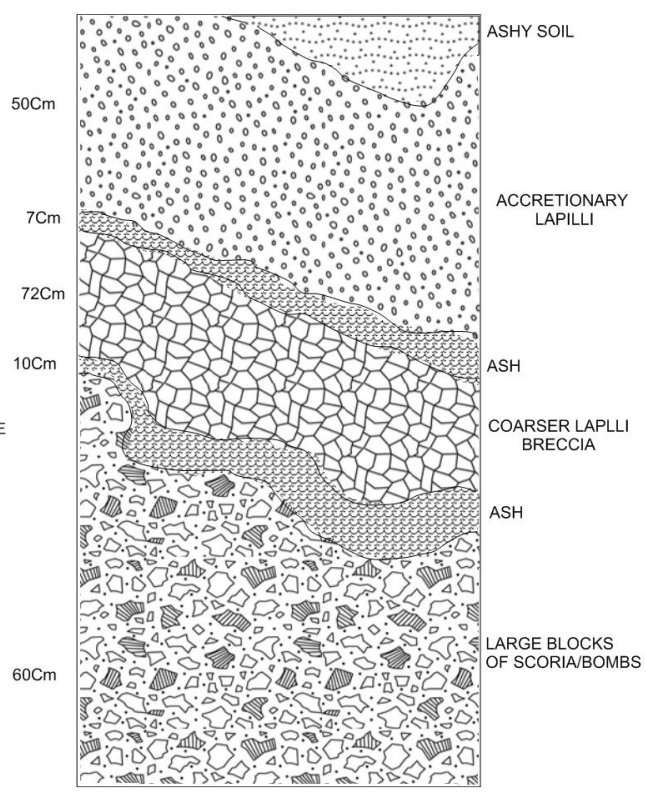

Figure 2: Tephrostratigraphic columns of the Bafmeng area, (A) sequence 1, (B) Sequence 2.
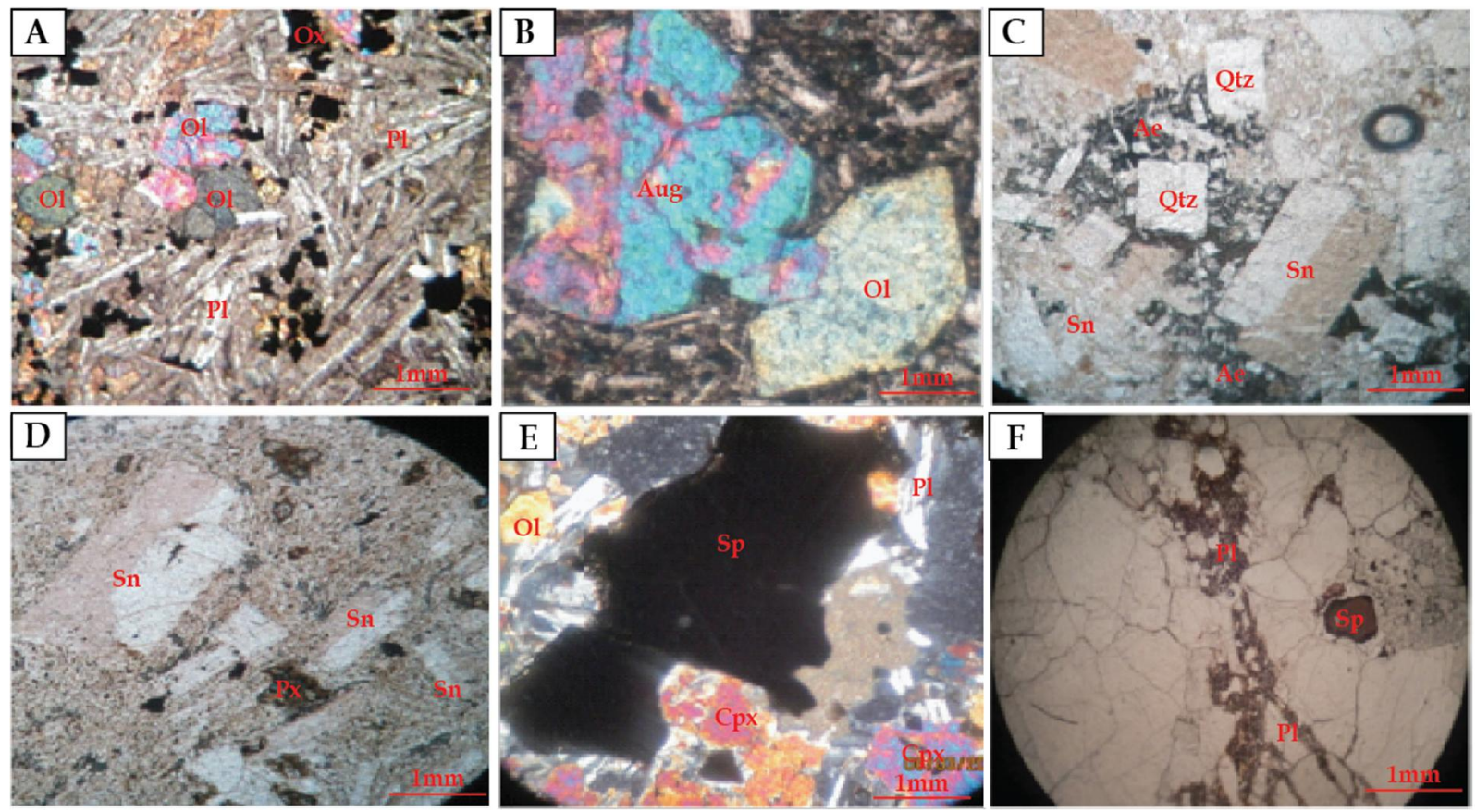

Figure 3: Photomicrography of representative thin sections (A) cluster of anhedral olivine from olivine basalts (B) association of olivine and augite (C) microphotography of rhyolite. (D) microphotography of trachyte (E) and (F) mantle xenoliths 


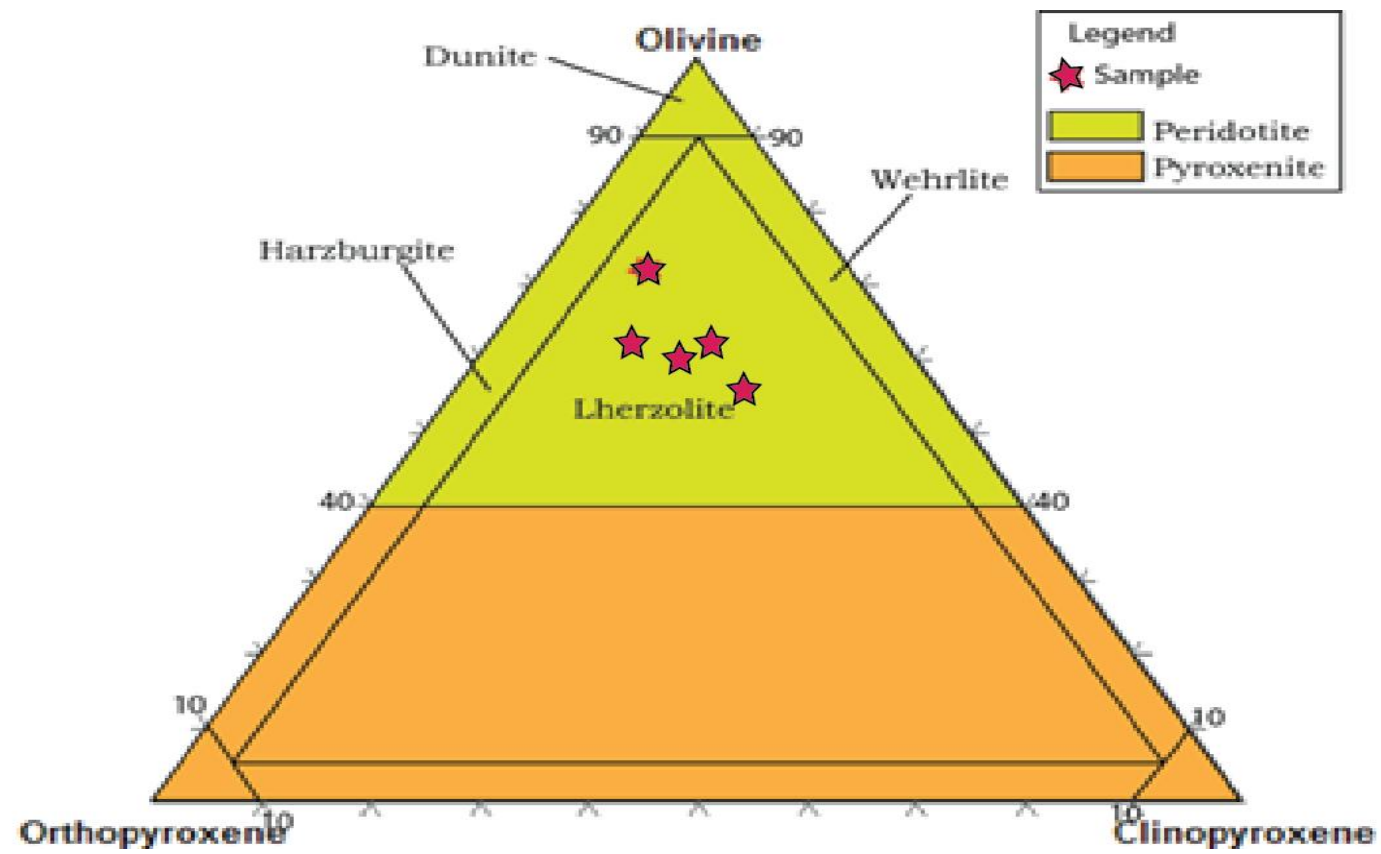

Figure 4: Modal classification of peridotite based on olivine, orthopyroxene and orthopyroxene (after Le Maitre, 2002).

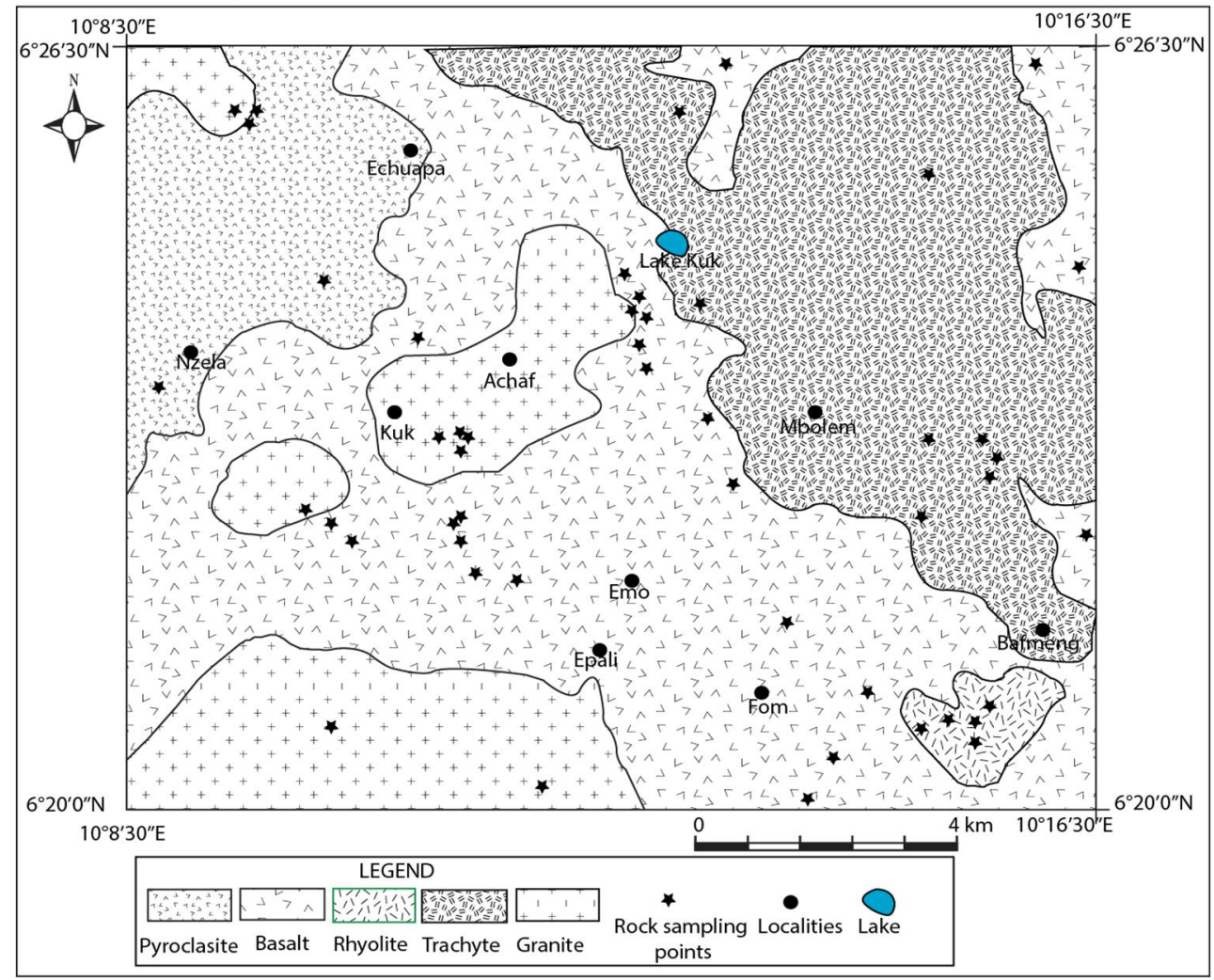

Figure 5: Geologic map of Bafmeng area. 


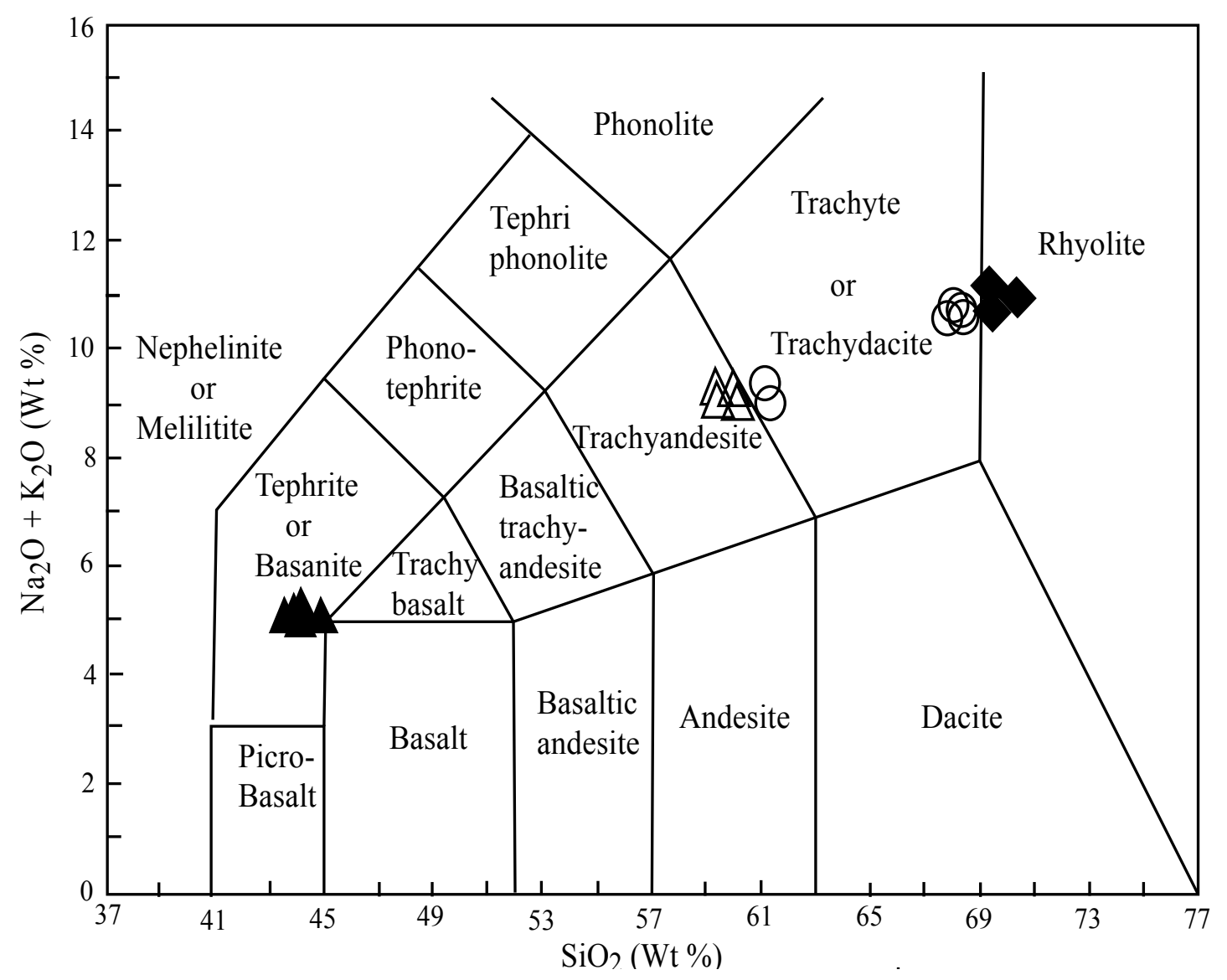

Figure 6: Total Alkali Silica (TAS) Diagram for lava of Bafmeng (Le Maitre, 2002).

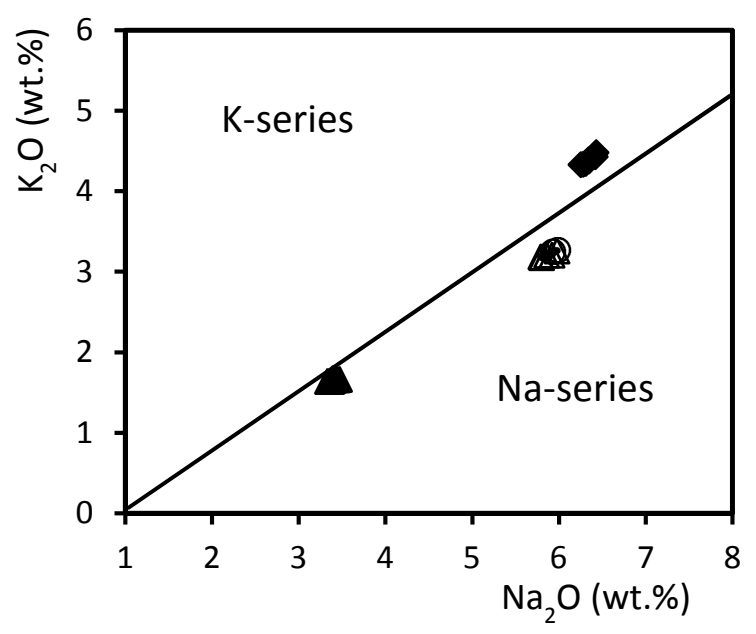

Figure 7: $\mathrm{Na} 2 \mathrm{O}$ vs. K2O subdivision diagram of the alkaline series (Middlemost 1975) of Bafmeng. 

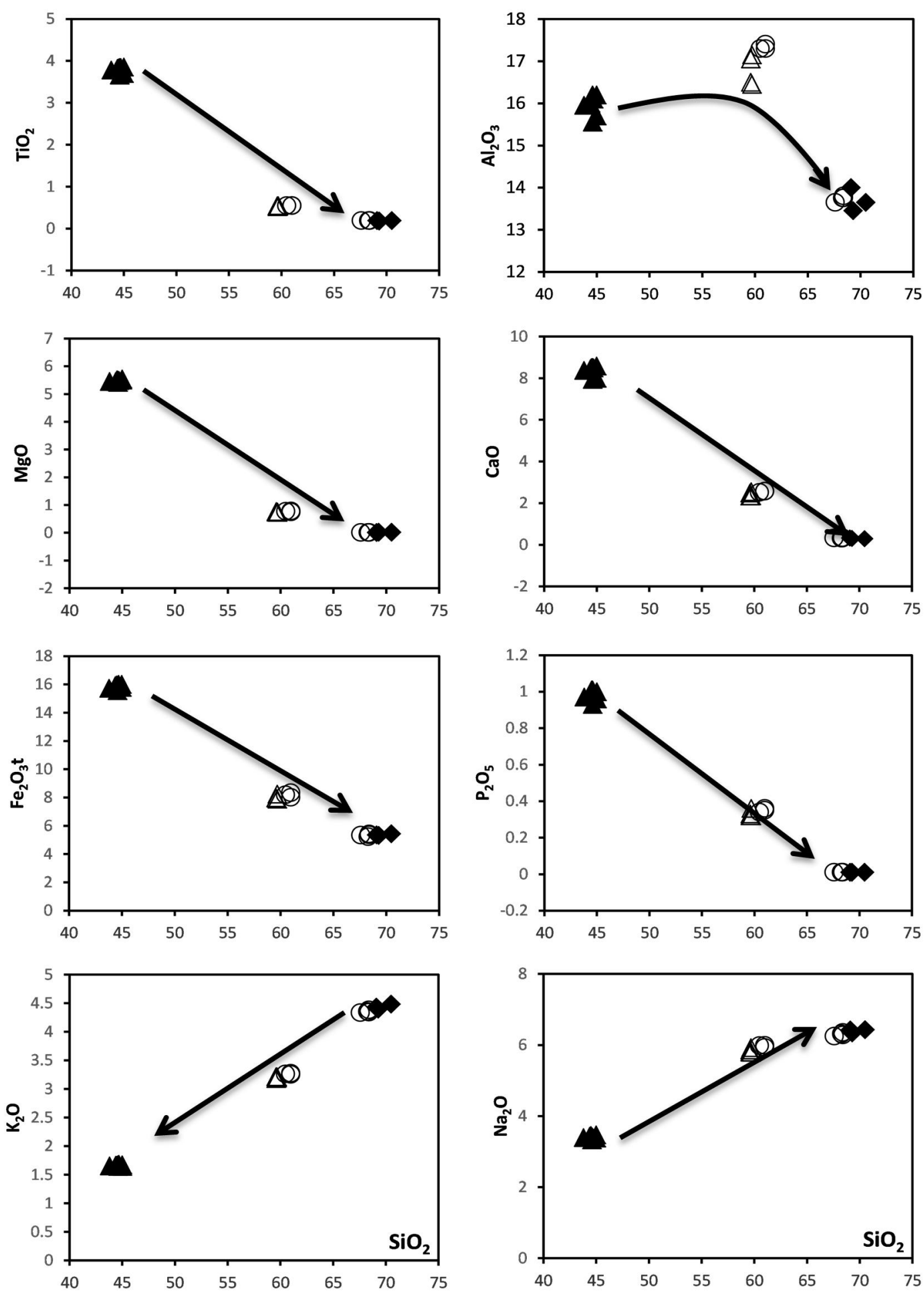

Figure 8: Variation of major element oxides (in wt. \% in Bafmeng lavas versus DI. Symbols are as follows: filled triangles=basanite; empty triangles=benmoreite; circles=trachyte; losanges=rhyolite. 


\section{DISCUSSION}

Magma fractionation

The TAS diagram shows a positive correlation between $\mathrm{Na}_{2} \mathrm{O}+\mathrm{K}_{2} \mathrm{O}$ and $\mathrm{SiO}_{2}$, in accordance with magmatic differentiation of a residual alkaline liquid (trachyte and rhyolite). This lava is fractionated with $\mathrm{Mg} \#$ of 39 to 0 . The binary diagrams for the major element (Figure 8) shows two types of evolution, a negative correlation with $\mathrm{SiO}_{2}, \mathrm{Fe}_{2} \mathrm{O}_{3}, \mathrm{MgO}$, $\mathrm{P}_{2} \mathrm{O}_{5}$, and $\mathrm{CaO}$ suggesting progressive fractional crystallisation of mafic minerals (olivine, clinopyroxene and basic plagioclases), even though the $\mathrm{CaO}$ content is also important in the intermediary lava and not totally absent in the acid lava. This shows that the lava fractionates some minerals rich in calcium (plagioclase and clinopyroxene). $\mathrm{P}_{2} \mathrm{O}_{5}$ varies from around $1 \%$ from the basic lava to 0 in the acid end indicating fractionation of apatite. The positive correlation of some elements $\left(\mathrm{Al}_{2} \mathrm{O}_{3}, \mathrm{Na}_{2} \mathrm{O}\right.$, and $\left.\mathrm{K}_{2} \mathrm{O}\right)$ is an evidence of crystallisation of alkaline minerals towards the most differentiated acid end compare to a decreasing content of mafic minerals. The concentrations of $\mathrm{Ni}, \mathrm{Cr}, \mathrm{Co}$ are less compared to the expected compositions of melts equivalent to primitive mantle. ( $\mathrm{Cr} ; 300$ 500 ppm, Ni; 300-400 ppm, Co; 50-70 ppm (Frey et al., 1978). This suggests that they have undergone extensive fractional crystallisation from the parent magma in the magmatic chambers or upon migration to the surface. $\mathrm{Ni}$, $\mathrm{Cu}, \mathrm{Co}, \mathrm{V}$ and $\mathrm{Sr}$ shows negative correlation with $\mathrm{SiO}_{2}$ suggesting it's an appropriate fractionation monitor. The existence of at least two different REE patterns (Figure 10) suggests that the trace element of the lavas resulted from the partial melting of a heterogeneous mantle

Comparison of the volcanic rocks of the Bafmeng rocks with few others along the CVL reveals some obvious similarities. The lavas of the study area fall within the alkaline series which are concordant to those of the Adamawa (Girod et al., 1987), Mount Cameroon (Wandji et al., 2009). , Wainama West (Wotchoko et al., 2016) Tombel graben (Nkouathio et al., 2008), Mount Manengouba (Pouclet et al., 2014), Mount Bamenda (Kamgang et al., 2013) and Mount Oku (Njilah et al., 2007). This confirms the fact that majority of the rocks along the CVL are alkaline in nature.

\section{Petrogenesis and partial melting}

The MORB normalised trace elements diagrams of the mafic lava shows that the Bafmeng profile are identical to that of the average OIB (McDonough, 2003) (Figure 12A) and shows a general OIB pattern with enrichment in LILE, LREE and HFSE.

A similar enriched mantle source can be assumed as shown on $\mathrm{Ta} / \mathrm{Yb}$ vs $\mathrm{Th} / \mathrm{Yb}$ diagram (Figure 12B). However, distinct $\mathrm{Zr} / \mathrm{Hf}$ and $\mathrm{Nb} / \mathrm{Ta}$ ratio shows that the Bafmeng mantle source is different from MORB but similar to those of the OIB, the continental basalts and the Kenya rift (Figure 12C). The $\mathrm{Zr} / \mathrm{Hf}$ ratios of the study area have values similar to those of the OIBs, whereas $\mathrm{Nb} / \mathrm{Ta}$ ratios tend to be higher. $\mathrm{The} \mathrm{Zr} / \mathrm{Hf}$ ratio ranges from 47.0 to 47.9 with an average of 47.45 and the $\mathrm{Nb} / \mathrm{Ta}$ ratio range from 17.7 to 18.0 with an average of 17.85 . The above values are respectively above and in the range of the OIB. (OIB: $\mathrm{Nb} / \mathrm{Ta}=15.9 \pm 0.6$, $\mathrm{Zr} / \mathrm{Hf}=35.5-45.5$ ) (Pfänder et al., 2007).

However, the $\mathrm{Nb} / \mathrm{Ta}$ ratio is slightly higher than the range obtained for the continental part of the CVL $(\mathrm{Nb} / \mathrm{Ta}=11.19$ 14.77) (Ngounouno et al., 2000, Nkouathio et al., 2008, Wandji et al., 2008, Kamgang et al., 2010) but it is within Oku volcanic group and Kenya rift.

Conclusively, Zhang et al. (2009) used the slightly higher $\mathrm{Nb} / \mathrm{Ta}$ and average $\mathrm{Zr} / \mathrm{Hf}$ ratio as evidence of derivation from distinct liquid relative to the others although sharing a 
common source region. This difference is only controlled by fractional crystallization.

In the $\mathrm{La} / \mathrm{Sm}$ vs $\mathrm{Sm} / \mathrm{Yb}$ diagram, (Figure 12D), the lava plots slightly close to the 50-50 spinel -garnet lherzolite melting curve. Comparing with data from Tsafack et al. (2009) there is also a mixing of spinel-garnet lherzolite in Mount Cameroon. It could be concluded that melting of mafic lavas of Bafmeng took place in the spinel to garnet transition zone (Schilling et al., 2005).

\section{Mantle upwelling}

The lithospheric mantle of the Bafmeng area is characterised by a porphyroblastic texture, exsolution of clinopyroxene, occurrence of melt veins, melt poles and is indicative of two stages of pressuretemperature equilibrium. Melt pockets together with their associated minerals are likely subsequent manifestation hence, rehomogenisation stage (Tamen et al., 2015). Therefore, the transition of spinel to plagioclase lherzolite in the mantle xenoliths of Bafmeng is governed by a continuous reaction resulting in a systematic compositional variation in coexisting minerals at decreasing pressure within the plagioclase stability field (Borghini et al., 2010). The development of a plagioclase bearing assemblage indicates that this peridotite have been partially reequilibrated at relatively low pressure, from spinel to plagioclase lherzolite facies condition (Rampone et al., 1995) and it turns out that, this type of peridotite at the initial state was at equilibrium at the spinel facies, but underwent a destabilisation and after re-equilibrium in the plagioclase facies (Tamen et al., 2015). An evidence of mantle exhumation from about 22$9 \mathrm{~km}$.

\section{Contamination and assimilation plots}

Fractionation of plagioclase and/or alkaline feldspars have successively two effects (arrow 1-2) (Figure 13A and Figure $13 \mathrm{~B}$ ) indicates a mantle source of mafic rocks (1) or assimilation for benmoreitic-trachytic pumice and lavas (2); the trend of fractionation is outlined (3). Some (BD7) of the rocks of Bafmeng area have rather high $\mathrm{Ba}$ contents (up to $1145 \mathrm{ppm}$ ) as well as high $\mathrm{Sr}$ content (up to $1090 \mathrm{ppm}$ ). The arrow indicates fractionation path from mafic to felsic rocks produced by fractionation, dominated first by olivine, clinopyroxene, plagioclases and/or alkaline feldspars. The high $\mathrm{Ba}$ and low $\mathrm{Sr}$ in some of the samples is explained by partial assimilation of granito-gneissic basement (Franz et al., 1999). Contamination of the melt with the basement is therefore a likely scenario to produce rocks which are transitional from benmoreite to trachyte to rhyolite. This is also seen illustrated in Figures 6 and 8, where the benmoreite is undergoing evolution to trachyte and trachyte to rhyolite. Conversely, the $\mathrm{Zr} / \mathrm{Nb}$ vs $\mathrm{Zr}$ diagram (Figure 13B) argues for more assimilation in some felsic samples, such as sample BD4 (trachyte) and BG3 (rhyolite) which have high $\mathrm{Zr} / \mathrm{Nb}$ ratios of 8.19 and 6.19 respectively for medium $\mathrm{Zr}$ contents of 1175 and $2290 \mathrm{ppm}$. In contrast, trachyte samples display considerably higher $\mathrm{Zr}$ values of 2290 and 2310 ppm (Table 2), clearly indicating a fractionation process. According to major element composition and in combination with the petrographic observation, we conclude that they are contaminated by assimilation of the basement rock.

\section{Geotectonic context}

The combined study of the volcanology, petrology and geochemistry has shown that the lava of the Bafmeng area is of within plate volcanic zone (Figure 13C). 

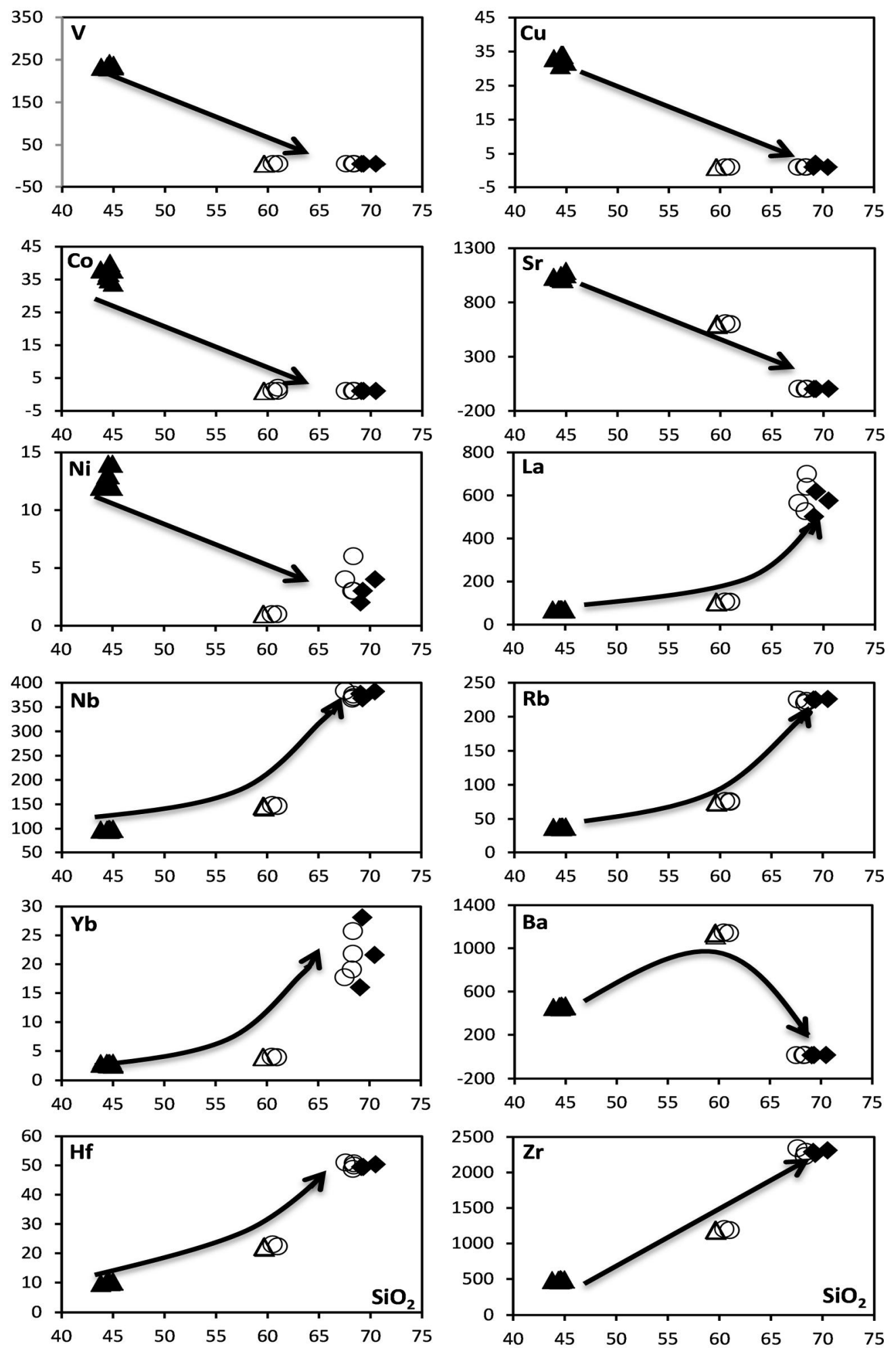

Figure 9: Trace elements variation diagrams. Symbols are as follows: filled triangles=basanite; empty triangles=benmoreite; circles $=$ trachyte; losanges $=$ rhyolite. 


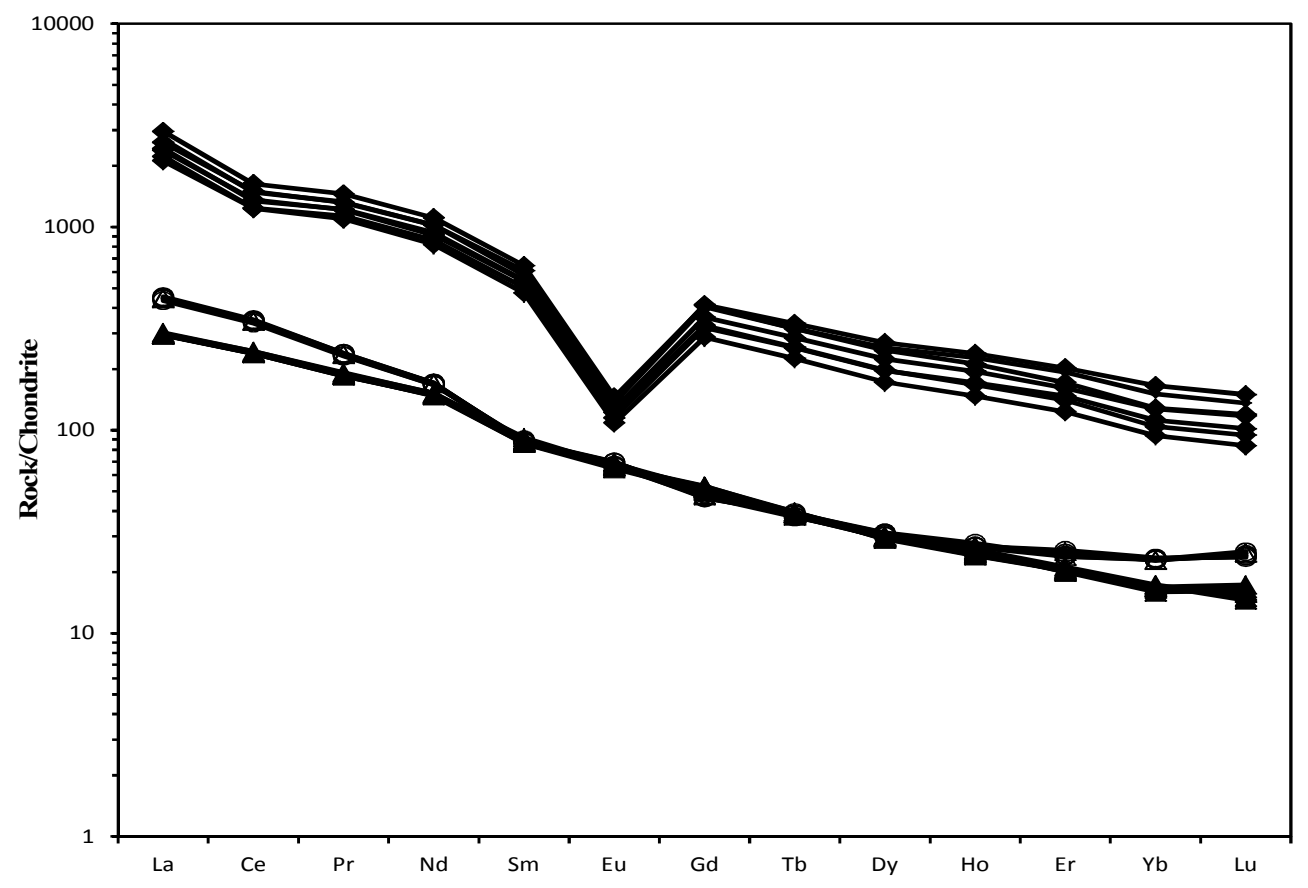

Figure 10: REE plot of the Bafmeng lava normalised with Chondrite (McDonough, 1995). Symbols are as follows: filled triangles=basanite; empty triangles=benmoreite; circles=trachyte; losanges=rhyolite.

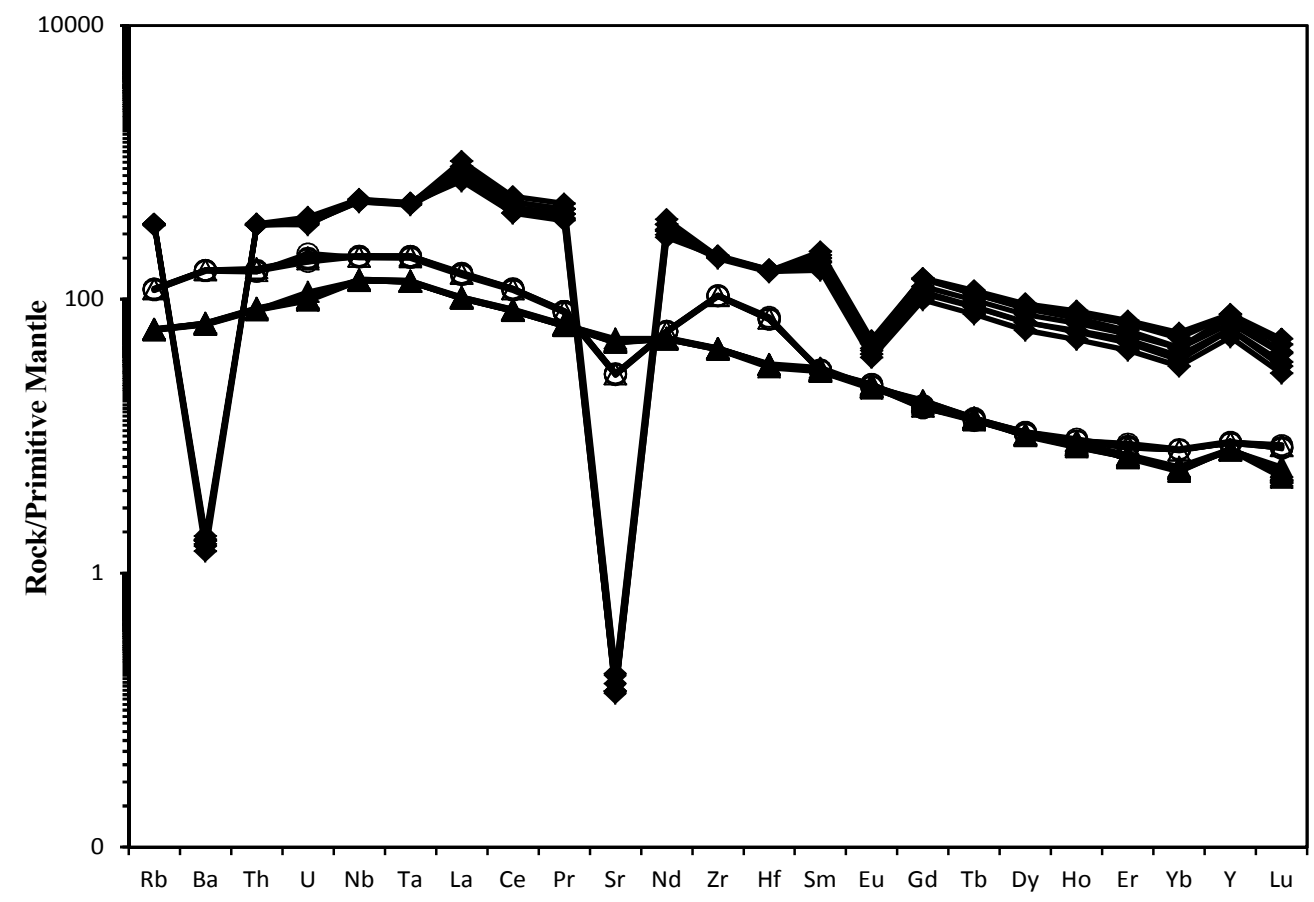

Figure 11: Primitive mantle normalised spider diagram of trace elements of the Bafmeng lava (Sun and McDonough, 1989). Symbols are as follows: filled triangles=basanite; empty triangles=benmoreite; circles=trachyte; losanges=rhyolite. 

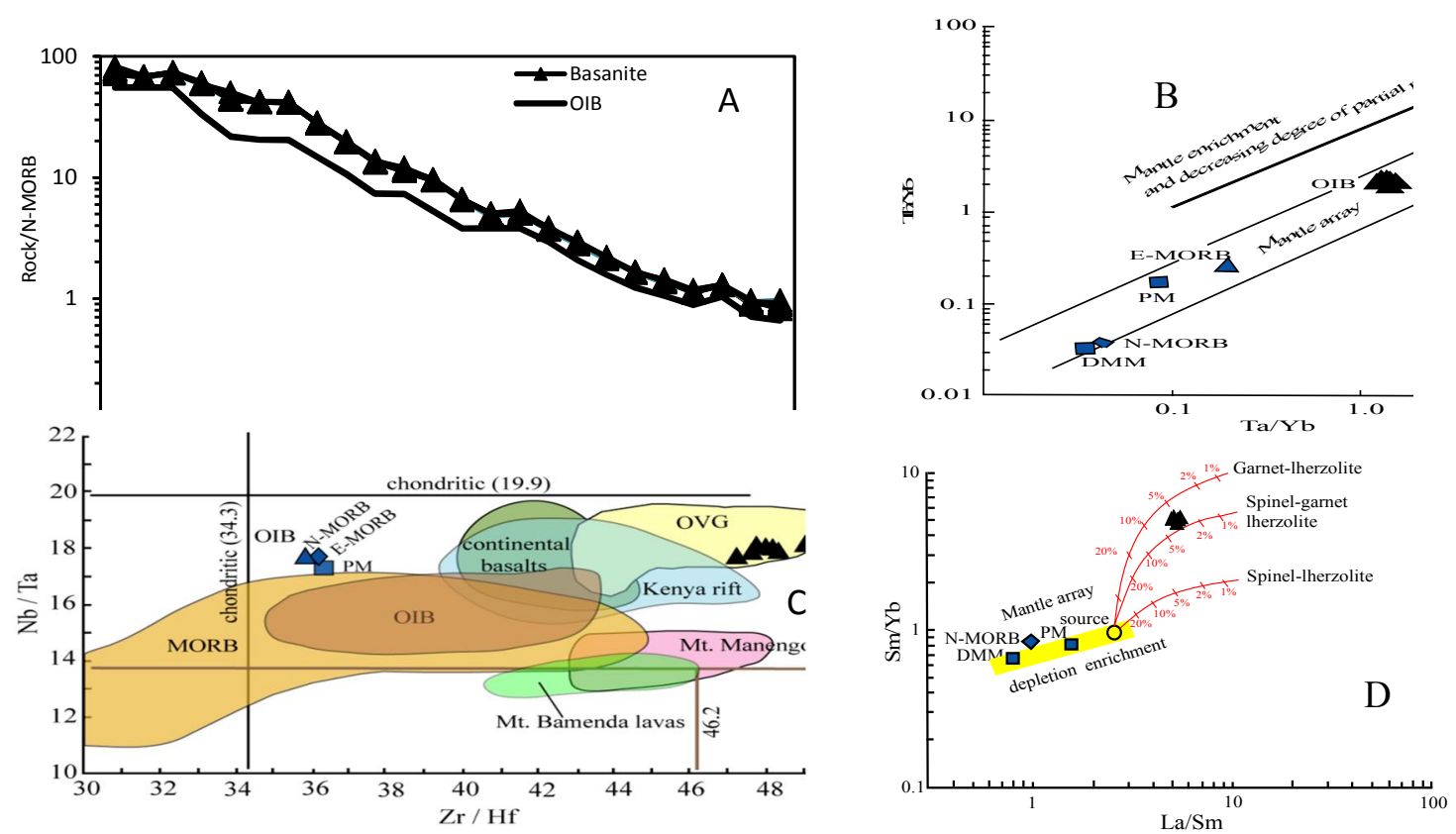

Fìgure 12 (A): N-MORB normalised trace element pattern restricted to mafic lava of the Bafmeng area (B): The Ta/YbvsTh/Yb diagram. PM, N-MORB, EMORB, and OIB (1989) and (C): Zr/Hf vs. $\mathrm{Nb}$ /Ta diagram. PM, N-MORB, EMORB, and OIB from Sun and McDonough (1989) (D): La/Sm vs. $\mathrm{Sm} / \mathrm{Yb}$ diagrams for determining the enrichment of the source and the partial melting degree of the mantle source.
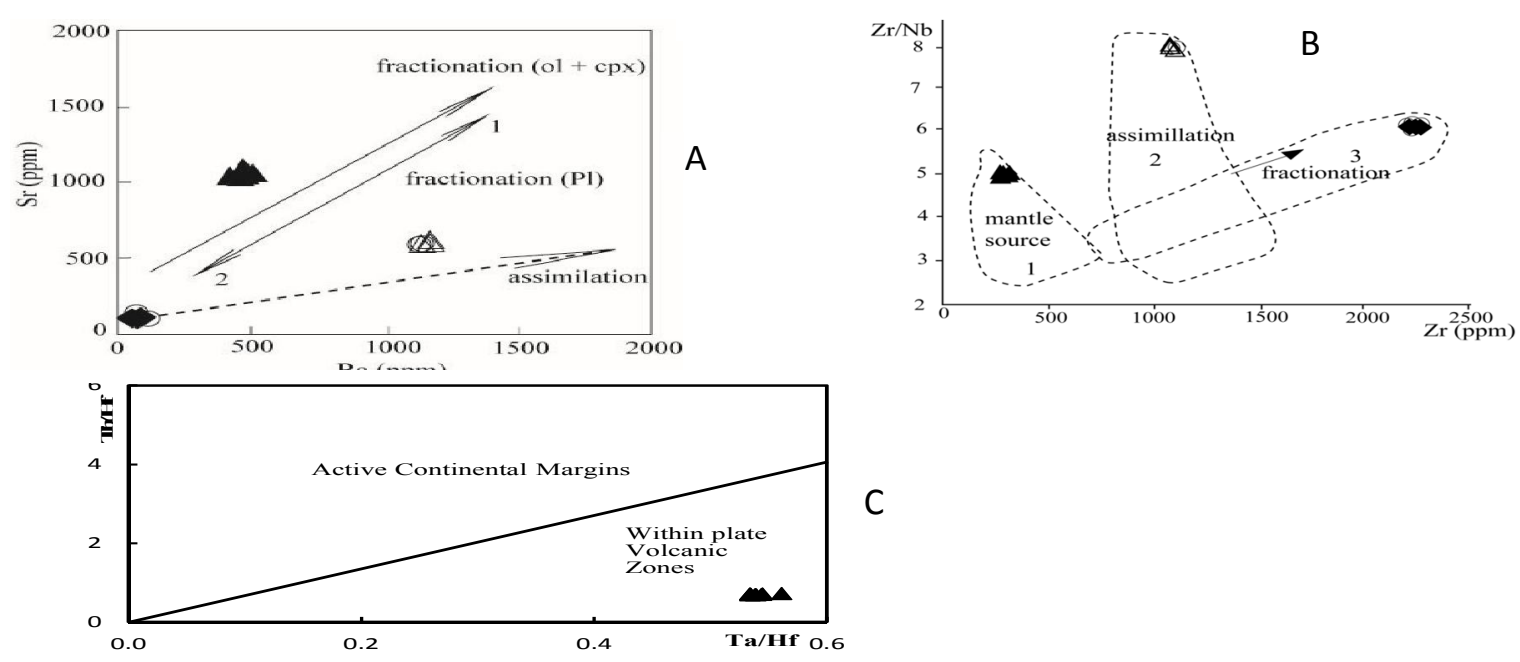

Figure 13: (A): Sr vs. Ba diagram for Bafmeng lavas; fractionation and assimilation trends are shown, dash dotted arrow is analysis of granite and gneisses from maars of the Meidob Hills (after Franz et al., 1999 modified). (B): Zr/Nb vs. Zr diagram for Bafmeng lavas. Dashed lines show fields of rocks of Meidob Hills, Sudan (Franz et al., 1999 modified). (C): Diagram showing the geotectonic context of the Bafmeng lava (Schandl and Gorton, 2002) Symbols are same as on binary plots 
M-L. V. CHENYI et al. / Int. J. Biol. Chem. Sci. 11(2): 841-864, 2017

Table 1: Geochemical analysis of major elements and CIPW norms (calculated with $1.5 \mathrm{~W} \% \mathrm{Fe}_{2} \mathrm{O}_{3}$ ) of lava from Bafmeng.

\begin{tabular}{|c|c|c|c|c|c|c|c|c|c|c|c|c|c|c|c|c|c|c|c|c|c|c|}
\hline & \multicolumn{8}{|c|}{ Basanite } & \multicolumn{4}{|c|}{ Benmoreite } & \multicolumn{7}{|c|}{ Trachyte } & \multicolumn{3}{|c|}{ Rhyolite } \\
\hline & BB1 & BB2 & BB3 & BB4 & BB5 & BB6 & BB7 & BB8 & BD2 & BD3 & BD4 & BD5 & BD1 & BD6 & BD7 & BG3 & BG4 & BG6 & BG7 & BG1 & BG2 & BG5 \\
\hline $\mathrm{SiO} 2$ & 44.6 & 45 & 44.5 & 44.6 & 43.8 & 45 & 44.4 & 44.7 & 59.6 & 59.7 & 59.7 & 59.6 & 60.5 & 61 & 61 & 68.4 & 67.6 & 68.4 & 68.3 & 69.3 & 70.5 & 69.1 \\
\hline $\mathrm{TiO} 2$ & 3.66 & 3.7 & 3.83 & 3.84 & 3.78 & 3.85 & 3.82 & 3.84 & 0.54 & 0.55 & 0.53 & 0.52 & 0.55 & 0.55 & 0.55 & 0.19 & 0.19 & 0.19 & 0.19 & 0.18 & 0.19 & 0.19 \\
\hline $\mathrm{A} 12 \mathrm{O} 3$ & 15.55 & 15.7 & 16.15 & 16.2 & 15.95 & 16.2 & 16 & 16.1 & 17.05 & 17.15 & 16.45 & 16.5 & 17.3 & 17.3 & 17.4 & 13.75 & 13.65 & 13.8 & 13.75 & 13.45 & 13.65 & 14 \\
\hline $\mathrm{Fe} 2 \mathrm{O} 3$ & 1.85 & 1.88 & 1.90 & 1.90 & 1.87 & 1.90 & 1.89 & 1.90 & 0.95 & 0.98 & 0.94 & 0.95 & 0.97 & 0.95 & 0.99 & 1.14 & 0.90 & 1.15 & 1.11 & 1.13 & 1.15 & 1.14 \\
\hline $\mathrm{FeO}$ & 12.34 & 12.51 & 12.64 & 12.64 & 12.47 & 12.69 & 12.60 & 12.69 & 6.33 & 6.53 & 6.25 & 6.31 & 6.49 & 6.34 & 6.61 & 3.80 & 3.99 & 3.83 & 3.69 & 3.77 & 3.84 & 3.80 \\
\hline $\mathrm{Fe} 2 \mathrm{O} 3 \mathrm{t}$ & 15.56 & 15.78 & 15.95 & 15.95 & 15.73 & 16.00 & 15.89 & 16.00 & 7.98 & 8.24 & 7.88 & 7.96 & 8.19 & 8.00 & 8.34 & 5.36 & 5.33 & 5.41 & 5.21 & 5.32 & 5.42 & 5.36 \\
\hline $\mathrm{FeO} \mathrm{t}$ & 14 & 14.2 & 14.35 & 14.35 & 14.15 & 14.4 & 14.3 & 14.4 & 7.18 & 7.41 & 7.09 & 7.16 & 7.37 & 7.2 & 7.5 & 4.82 & 4.8 & 4.87 & 4.69 & 4.79 & 4.88 & 4.82 \\
\hline $\mathrm{MnO}$ & 0.19 & 0.2 & 0.21 & 0.21 & 0.21 & 0.21 & 0.21 & 0.21 & 0.18 & 0.27 & 0.16 & 0.17 & 0.18 & 0.2 & 0.18 & 0.12 & 0.12 & 0.12 & 0.12 & 0.11 & 0.12 & 0.11 \\
\hline $\mathrm{MgO}$ & 5.42 & 5.5 & 5.51 & 5.5 & 5.45 & 5.54 & 5.45 & 5.48 & 0.74 & 0.73 & 0.75 & 0.76 & 0.77 & 0.75 & 0.78 & 0.01 & 0.01 & 0.01 & 0.01 & 0.02 & 0.02 & 0.01 \\
\hline $\mathrm{CaO}$ & 7.94 & 7.99 & 8.5 & 8.51 & 8.37 & 8.58 & 8.44 & 8.49 & 2.48 & 2.55 & 2.35 & 2.34 & 2.51 & 2.57 & 2.57 & 0.31 & 0.32 & 0.33 & 0.31 & 0.3 & 0.29 & 0.32 \\
\hline $\mathrm{Na} 2 \mathrm{O}$ & 3.33 & 3.38 & 3.45 & 3.42 & 3.39 & 3.47 & 3.43 & 3.39 & 5.86 & 5.92 & 5.79 & 5.8 & 5.98 & 5.93 & 5.99 & 6.28 & 6.25 & 6.35 & 6.31 & 6.34 & 6.43 & 6.42 \\
\hline $\mathrm{K} 2 \mathrm{O}$ & 1.64 & 1.64 & 1.66 & 1.67 & 1.65 & 1.67 & 1.66 & 1.68 & 3.21 & 3.21 & 3.19 & 3.18 & 3.26 & 3.25 & 3.27 & 4.34 & 4.33 & 4.38 & 4.35 & 4.39 & 4.48 & 4.43 \\
\hline \multirow{2}{*}{$\begin{array}{l}\mathrm{P} 2 \mathrm{O} 5 \\
\mathrm{Mg} \#\end{array}$} & 0.93 & 0.96 & 1.01 & 1.01 & 0.97 & 1 & 0.98 & 0.99 & 0.33 & 0.36 & 0.32 & 0.32 & 0.34 & 0.36 & 0.35 & 0.01 & 0.01 & 0.01 & 0.01 & 0.01 & 0.01 & 0.01 \\
\hline & 39.46 & 39.47 & 39.27 & 39.22 & 39.34 & 39.31 & 39.09 & 39.05 & 14.79 & 14.23 & 15.12 & 15.16 & 14.96 & 14.92 & 14.90 & 0.35 & 0.35 & 0.34 & 0.36 & 0.70 & 0.69 & 0.35 \\
\hline
\end{tabular}


M-L. V. CHENYI et al. / Int. J. Biol. Chem. Sci. 11(2): 841-864, 2017

\begin{tabular}{|c|c|c|c|c|c|c|c|c|c|c|c|c|c|c|c|c|c|c|c|c|c|c|}
\hline TOTAL & 97.45 & 98.46 & 99.36 & 99.50 & 97.91 & 100.11 & 98.88 & 99.47 & 97.27 & 97.95 & 96.42 & 96.44 & 98.86 & 99.21 & 99.69 & 98.34 & 97.37 & 98.58 & 98.15 & 99.00 & 100.69 & 99.52 \\
\hline \multicolumn{23}{|l|}{$\begin{array}{l}\text { Norme } \\
\text { CIPW }\end{array}$} \\
\hline Quartz & - & - & - & - & - & - & - & - & 3.15 & 2.59 & 4.12 & 3.92 & 2.90 & 3.79 & 3.08 & 14.52 & 14.28 & 14.17 & 14.53 & 16.16 & 16.28 & 14.11 \\
\hline Orthose & 9.95 & 9.84 & 9.87 & 9.92 & 9.96 & 9.86 & 9.92 & 9.98 & 19.50 & 19.37 & 19.55 & 19.49 & 19.49 & 19.36 & 19.38 & 26.08 & 26.28 & 26.26 & 26.19 & 26.20 & 26.29 & 26.30 \\
\hline Albite & 24.80 & 24.88 & 21.29 & 21.45 & 20.93 & 21.65 & 21.53 & 21.73 & 50.98 & 51.14 & 50.81 & 50.89 & 51.19 & 50.58 & 50.84 & 47.34 & 47.35 & 47.27 & 47.38 & 45.19 & 44.96 & 47.57 \\
\hline Anorthite & 23.23 & 23.18 & 23.83 & 24.04 & 23.93 & 23.67 & 23.62 & 23.88 & 10.43 & 10.51 & 9.82 & 9.87 & 10.35 & 10.48 & 10.50 & - & - & - & - & - & - & - \\
\hline Acmite & - & - & - & - & - & - & - & - & - & - & - & - & - & - & - & 3.35 & 2.67 & 3.38 & 3.27 & 3.31 & 3.31 & 3.31 \\
\hline Néphéline & 2.23 & 2.26 & 4.39 & 4.14 & 4.53 & 4.16 & 4.24 & 3.85 & - & - & - & - & - & - & - & - & - & - & - & - & - & - \\
\hline Diopside & 9.11 & 8.90 & 9.95 & 9.77 & 9.98 & 10.24 & 10.18 & 9.95 & 0.00 & - & 0.09 & - & 0.00 & - & - & 1.33 & 1.39 & 1.42 & 1.34 & 1.28 & 1.21 & 1.36 \\
\hline Hypersthène & - & - & - & - & - & - & - & - & 12.46 & 12.86 & 12.39 & 12.60 & 12.61 & 12.29 & 12.72 & 6.31 & 6.72 & 6.32 & 6.13 & 6.27 & 6.32 & 6.19 \\
\hline Olivine & 18.59 & 18.78 & 18.24 & 18.24 & 18.27 & 18.05 & 18.10 & 18.20 & - & - & - & - & - & - & - & - & - & - & - & - & - & - \\
\hline Magnétite & 2.75 & 2.76 & 2.77 & 2.76 & 2.77 & 2.76 & 2.77 & 2.77 & 1.41 & 1.45 & 1.41 & 1.42 & 1.43 & 1.39 & 1.44 & 0.00 & 0.00 & 0.00 & 0.00 & 0.00 & 0.00 & 0.00 \\
\hline Ilménite & 7.13 & 7.14 & 7.32 & 7.33 & 7.33 & 7.30 & 7.34 & 7.33 & 1.05 & 1.07 & 1.04 & 1.02 & 1.06 & 1.05 & 1.05 & 0.37 & 0.37 & 0.37 & 0.37 & 0.35 & 0.36 & 0.36 \\
\hline Apatite & 2.21 & 2.26 & 2.36 & 2.35 & 2.30 & 2.31 & 2.30 & 2.31 & 0.79 & 0.85 & 0.77 & 0.77 & 0.80 & 0.84 & 0.81 & 0.02 & 0.02 & 0.02 & 0.02 & 0.02 & 0.02 & 0.02 \\
\hline TOTAL & 100 & 100 & 100 & 100 & 100 & 100 & 100 & 100 & 100 & 100 & 100 & 100 & 100 & 100 & 100 & 100 & 100 & 100 & 100 & 100 & 100 & 100 \\
\hline Norm Pl & 44.89 & 44.73 & 45.46 & 45.89 & 45.66 & 45.30 & 45.24 & 45.90 & 16.99 & 17.05 & 16.20 & 16.24 & 16.82 & 17.16 & 17.11 & - & - & - & - & - & - & - \\
\hline DI & 36.98 & 36.98 & 35.54 & 35.50 & 35.42 & 35.67 & 35.69 & 35.56 & 73.63 & 73.10 & 74.48 & 74.29 & 73.58 & 73.73 & 73.31 & 87.94 & 87.91 & 87.70 & 88.11 & 87.55 & 87.53 & 87.99 \\
\hline
\end{tabular}


Table 2: Selected Trace elements (concentration in ppm) for Bafmeng Lava.

\begin{tabular}{|c|c|c|c|c|c|c|c|c|c|c|c|c|c|c|c|c|c|c|c|c|c|c|}
\hline & \multicolumn{8}{|c|}{ Basanite } & \multicolumn{4}{|c|}{ Benmoreite } & \multicolumn{7}{|c|}{ Trachyte } & \multicolumn{3}{|c|}{ Rhyolite } \\
\hline & BB1 & BB2 & BB3 & BB4 & BB5 & BB6 & BB7 & BB8 & BD2 & BD3 & BD4 & BD5 & BD1 & BD6 & BD7 & BG3 & BG4 & BG6 & BG7 & BG1 & BG2 & BG5 \\
\hline As & 0.6 & 0.6 & 0.5 & 0.7 & 0.7 & 0.4 & 0.7 & 0.5 & 1.9 & 1.5 & 1.7 & 1.6 & 1.8 & 2 & 1.8 & 0.1 & 0.1 & 0.1 & 0.1 & 0.1 & 0.1 & 0.1 \\
\hline $\mathrm{Ba}$ & 468 & 470 & 455 & 462 & 457 & 462 & 465 & 460 & 1140 & 1145 & 1120 & 1135 & 1145 & 1140 & 1140 & 12.1 & 11 & 12 & 11.4 & 12.3 & 13 & 10.1 \\
\hline $\mathrm{Ce}$ & 149 & 149.5 & 145.5 & 146 & 146 & 147 & 147 & 146.5 & 212 & 210 & 206 & 211 & 214 & 210 & 211 & 906 & 834 & 1000 & 758 & 917 & 821 & 754 \\
\hline Co & 37 & 38 & 37 & 35 & 38 & 34 & 36 & 40 & 1 & 0.99 & 1 & 0.99 & 1 & 1 & 2 & 0.99 & 0.99 & 0.99 & 0.99 & 0.99 & 1 & 0.99 \\
\hline $\mathrm{Cr}$ & 10 & 10 & 10 & 10 & 10 & 10 & 10 & 10 & 10 & 10 & 10 & 10 & 10 & 10 & 10 & 10 & 10 & 10 & 10 & 10 & 10 & 10 \\
\hline $\mathrm{Cu}$ & 32 & 32 & 34 & 34 & 33 & 32 & 31 & 34 & 1 & 1 & 1 & 1 & 1 & 1 & 1 & 1 & 1 & 1 & 1 & 2 & 1 & 1 \\
\hline Dy & 7.52 & 7.55 & 7.39 & 7.57 & 7.48 & 7.36 & 7.51 & 7.6 & 7.8 & 7.68 & 7.64 & 7.93 & 7.91 & 7.52 & 7.68 & 64.7 & 50.2 & 62.8 & 49.9 & 68.5 & 56.9 & 43.8 \\
\hline $\mathrm{Er}$ & 3.48 & 3.31 & 3.37 & 3.41 & 3.37 & 3.51 & 3.31 & 3.45 & 4 & 4.1 & 4.02 & 3.96 & 4.24 & 3.96 & 4.18 & 31.9 & 23.2 & 28.4 & 24.3 & 33.5 & 26.7 & 20.4 \\
\hline $\mathrm{Eu}$ & 3.97 & 3.88 & 3.83 & 3.84 & 3.74 & 3.84 & 3.81 & 3.84 & 3.91 & 3.86 & 3.87 & 4.05 & 4.03 & 3.98 & 4.03 & 7.95 & 7.08 & 8.43 & 6.67 & 8.09 & 7.35 & 6.3 \\
\hline $\mathrm{Ga}$ & 26.7 & 26.6 & 26.1 & 25.8 & 25.8 & 26.5 & 26 & 26.3 & 26.3 & 25.6 & 25.6 & 26.4 & 26.2 & 25.8 & 25.9 & 52.2 & 52.1 & 52.9 & 51.3 & 52.2 & 51.9 & 52.5 \\
\hline $\mathrm{Gd}$ & 10.6 & 10.7 & 10.55 & 10.65 & 10.25 & 10.65 & 10.85 & 10.9 & 9.53 & 9.68 & 9.93 & 9.55 & 10.05 & 9.84 & 9.77 & 83.3 & 67.3 & 84.5 & 65.6 & 85.1 & 73.8 & 58.9 \\
\hline $\mathrm{Hf}$ & 10.3 & 10.4 & 10.2 & 10.3 & 9.8 & 10.3 & 10.3 & 10.1 & 22.2 & 22.4 & 21.9 & 22.2 & 23 & 22.3 & 22.3 & 50.7 & 51 & 49.9 & 48.8 & 49.5 & 50.4 & 49.5 \\
\hline $\mathrm{La}$ & 71 & 71.5 & 69.6 & 70 & 69.7 & 69.9 & 70.5 & 70 & 106.5 & 105.5 & 103 & 105 & 107.5 & 105 & 106 & 640 & 565 & 700 & 527 & 618 & 576 & 502 \\
\hline $\mathrm{Li}$ & 20 & 10 & 20 & 20 & 20 & 20 & 20 & 10 & 20 & 20 & 20 & 20 & 20 & 20 & 20 & 50 & 50 & 50 & 50 & 50 & 50 & 50 \\
\hline $\mathrm{Lu}$ & 0.42 & 0.41 & 0.4 & 0.4 & 0.44 & 0.38 & 0.37 & 0.42 & 0.64 & 0.61 & 0.61 & 0.62 & 0.6 & 0.63 & 0.63 & 3.45 & 2.4 & 3.04 & 2.58 & 3.8 & 2.98 & 2.13 \\
\hline Mo & 3 & 2 & 5 & 2 & 4 & 2 & 4 & 3 & 6 & 6 & 7 & 6 & 6 & 7 & 6 & 2 & 3 & 4 & 4 & 2 & 3 & 3 \\
\hline $\mathrm{Nb}$ & 99 & 99.3 & 97.2 & 97.5 & 97.7 & 99.7 & 97.9 & 98.2 & 147 & 146.5 & 143.5 & 145.5 & 148.5 & 146.5 & 146 & 370 & 383 & 375 & 367 & 368 & 382 & 377 \\
\hline $\mathrm{Nd}$ & 71.2 & 70.7 & 69.3 & 69.8 & 69.1 & 69.9 & 70.1 & 68.7 & 79.2 & 79 & 78 & 77.9 & 79.7 & 78.7 & 79.6 & 477 & 426 & 518 & 401 & 477 & 437 & 383 \\
\hline
\end{tabular}


M-L. V. CHENYI et al. / Int. J. Biol. Chem. Sci. 11(2): 841-864, 2017

\begin{tabular}{|c|c|c|c|c|c|c|c|c|c|c|c|c|c|c|c|c|c|c|c|c|c|c|}
\hline $\mathrm{Ni}$ & 14 & 12 & 13 & 12 & 12 & 14 & 13 & 13 & 1 & 0.99 & 1 & 1 & 0.99 & 0.99 & 0.99 & 3 & 4 & 6 & 3 & 3 & 4 & 2 \\
\hline $\mathrm{Pb}$ & 1.97 & 1.98 & 1.99 & 1.99 & 1.99 & 1.99 & 1.99 & 2 & 1.99 & 4 & 1.98 & 2 & 8 & 3 & 2 & 33 & 36 & 32 & 28 & 29 & 33 & 37 \\
\hline $\operatorname{Pr}$ & 18.05 & 18.2 & 17.55 & 17.55 & 17.65 & 18.05 & 17.8 & 17.75 & 22.7 & 22.5 & 22 & 22.2 & 22.7 & 22.5 & 22.4 & 126 & 115.5 & 138 & 107.5 & 125.5 & 116 & 104 \\
\hline $\mathrm{Rb}$ & 38.3 & 38.2 & 37.8 & 37.7 & 37.9 & 38.7 & 38.3 & 38.4 & 75.4 & 73.8 & 74.3 & 75.5 & 76.2 & 75.8 & 74.9 & 223 & 225 & 223 & 220 & 225 & 226 & 225 \\
\hline $\mathrm{Sb}$ & 0.1 & 0.09 & 0.09 & 0.1 & 0.1 & 0.09 & 0.11 & 0.1 & 0.15 & 0.16 & 0.14 & 0.14 & 0.14 & 0.14 & 0.16 & 0.09 & 0.1 & 0.1 & 0.09 & 0.08 & 0.09 & 0.11 \\
\hline $\mathrm{Sc}$ & 14 & 14 & 15 & 15 & 15 & 14 & 14 & 15 & 3 & 3 & 3 & 3 & 3 & 3 & 3 & 1 & 1 & 1 & 1 & 1 & 1 & 1 \\
\hline $\mathrm{Se}$ & 1.4 & 1.5 & 1.4 & 1.4 & 1.7 & 1.5 & 1.5 & 1.5 & 0.9 & 0.9 & 0.8 & 0.9 & 0.9 & 0.9 & 0.9 & 8.3 & 6.4 & 8.3 & 6.4 & 9.1 & 7.2 & 5.7 \\
\hline Sm & 13.2 & 14.05 & 13.55 & 13.35 & 13.15 & 13.7 & 13.35 & 13.15 & 13.5 & 13.45 & 13.7 & 13.5 & 13.3 & 13.25 & 13.45 & 88.6 & 82.6 & 98.7 & 77.1 & 93.2 & 83.7 & 72.4 \\
\hline Sn & 3 & 3 & 3 & 3 & 3 & 3 & 3 & 3 & 4 & 4 & 4 & 4 & 4 & 4 & 4 & 12 & 12 & 12 & 12 & 12 & 12 & 12 \\
\hline $\mathrm{Sr}$ & 1035 & 1060 & 1050 & 1015 & 1035 & 1090 & 1025 & 1015 & 601 & 605 & 590 & 596 & 608 & 600 & 598 & 2.9 & 3.3 & 3.9 & 2.8 & 2.9 & 3.8 & 2.9 \\
\hline Тa & 5.5 & 5.6 & 5.5 & 5.5 & 5.5 & 5.6 & 5.5 & 5.5 & 8.4 & 8.3 & 8.2 & 8.5 & 8.5 & 8.5 & 8.3 & 20.7 & 20.8 & 20.3 & 20 & 20.3 & 20.6 & 20.6 \\
\hline $\mathrm{Tb}$ & 1.43 & 1.44 & 1.46 & 1.46 & 1.41 & 1.48 & 1.48 & 1.46 & 1.47 & 1.4 & 1.41 & 1.45 & 1.44 & 1.41 & 1.44 & 11.8 & 9.58 & 11.85 & 9.49 & 12.5 & 10.65 & 8.42 \\
\hline $\mathrm{Te}$ & 0.01 & 0.01 & 0.01 & 0.02 & 0.02 & 0.02 & 0.02 & 0.02 & 0.01 & 0.01 & 0.01 & 0.01 & 0.01 & 0.01 & 0.01 & 0.04 & 0.04 & 0.04 & 0.04 & 0.04 & 0.04 & 0.04 \\
\hline Th & 7.37 & 7.26 & 7.07 & 7.1 & 7.08 & 7.16 & 7.28 & 7.24 & 13.55 & 13.65 & 13.5 & 13.75 & 13.95 & 13.65 & 14.3 & 29.6 & 30.3 & 29.8 & 29.5 & 29.5 & 29.9 & 29.8 \\
\hline $\mathrm{Tl}$ & 0.02 & 0.02 & 0.02 & 0.02 & 0.02 & 0.02 & 0.02 & 0.02 & 0.02 & 0.02 & 0.02 & 0.02 & 0.02 & 0.02 & 0.02 & 0.18 & 0.15 & 0.17 & 0.16 & 0.2 & 0.19 & 0.14 \\
\hline $\mathrm{Tm}$ & 0.49 & 0.46 & 0.47 & 0.48 & 0.48 & 0.51 & 0.45 & 0.49 & 0.6 & 0.64 & 0.62 & 0.6 & 0.65 & 0.62 & 0.59 & 4.47 & 3.13 & 4.03 & 3.33 & 4.84 & 3.79 & 2.83 \\
\hline $\mathrm{U}$ & 2.13 & 2.12 & 2.05 & 2.38 & 2.08 & 2.14 & 2.08 & 2.08 & 4.17 & 3.94 & 4.53 & 4.1 & 4.22 & 4.24 & 4.11 & 7.51 & 8.37 & 7.83 & 7.77 & 7.53 & 7.35 & 7.79 \\
\hline V & 242 & 234 & 232 & 235 & 233 & 238 & 235 & 237 & 5 & 5 & 5 & 5 & 5 & 5 & 5 & 5 & 5 & 5 & 5 & 5 & 5 & 5 \\
\hline Y & 36.6 & 36.4 & 35.7 & 35.9 & 35.9 & 36.6 & 36.1 & 36.4 & 41 & 40.5 & 40.3 & 40.9 & 41.6 & 40.8 & 40.9 & 351 & 273 & 339 & 276 & 354 & 304 & 241 \\
\hline $\mathrm{Yb}$ & 2.74 & 2.71 & 2.8 & 2.85 & 2.87 & 2.95 & 2.92 & 2.85 & 3.92 & 3.93 & 3.93 & 3.93 & 3.99 & 3.91 & 3.87 & 25.7 & 17.7 & 21.8 & 19.05 & 28.1 & 21.6 & 16 \\
\hline $\mathrm{Zn}$ & 135 & 139 & 143 & 139 & 141 & 135 & 136 & 146 & 134 & 130 & 131 & 127 & 135 & 131 & 133 & 1450 & 947 & 1305 & 1020 & 1535 & 1390 & 882 \\
\hline $\mathrm{Zr}$ & 493 & 492 & 479 & 488 & 481 & 490 & 485 & 484 & 1190 & 1190 & 1175 & 1185 & 1200 & 1185 & 1185 & 2290 & 2340 & 2290 & 2230 & 2260 & 2310 & 2290 \\
\hline
\end{tabular}


M-L. V. CHENYI et al. / Int. J. Biol. Chem. Sci. 11(2): 841-864, 2017

Table 3: Average ratios of incompatible trace elements of basalts from Bafmeng compared with those of Manengouba, Tombel, Bambouto and Bamenda Mountains with mantellic poles (OIB, primitive mantle, E MORB, N MORB, EMI and EMII, HIMU). (Saunders et al., 1988; Sun and McDonough, 1989; weaver, 1991; Kamgang, 2003; N'ni, 2004, Nkouathio et al., 2008).

\begin{tabular}{|c|c|c|c|c|c|c|c|c|c|}
\hline Domains & $\mathrm{Zr} / \mathrm{Nb}$ & $\mathrm{La} / \mathrm{Nb}$ & $\mathbf{B a} / \mathbf{N b}$ & Ba/Th & $\mathbf{R b} / \mathbf{N b}$ & $\mathrm{K} / \mathbf{N b}$ & Th/Nb & Th/La & $\mathrm{Ba} / \mathrm{La}$ \\
\hline Chondrite & 15.7 & 0.96 & 9.8 & 83 & 9.4 & 2215 & 0.117 & 0.122 & 10.16 \\
\hline Primitive Mantle & 14.8 & 0.94 & 9 & 77 & 0.91 & 323 & 0.117 & 0.125 & 9.6 \\
\hline N MORB & 30 & 1.07 & 4.3 & 60 & 0.36 & 296 & 0.071 & 0.067 & 4 \\
\hline E MORB & 8.8 & 0.76 & 6.87 & 95 & 0.61 & 253 & 0.07 & 0.1 & 9.05 \\
\hline $\mathrm{CC}$ & 16.2 & 2.2 & 54 & 124 & 4.7 & 1341 & 0.44 & 0.204 & 25 \\
\hline OIB Average & 5.8 & 0.77 & 7.3 & 88 & 0.64 & 250 & 0.083 & 0.108 & 9.4 \\
\hline HIMU & $3.2-5$ & $0.66-0.77$ & $4.9-6.5$ & $49-77$ & $0.35-0.38$ & $77-179$ & $0.078-0.101$ & $0.107-0.133$ & $6.9-8.7$ \\
\hline EMI & $4.2-11.4$ & $0.64-1.19$ & $11.4-17.7$ & $103-154$ & $0.88-1.17$ & $204-432$ & $0.105-0.122$ & $0.107-0.128$ & $13.2-16.9$ \\
\hline EMII & $4.5-7.3$ & 0.89-1.09 & $7.3-11$ & $67-84$ & $0.59-0.85$ & $248-378$ & $0.111-0.157$ & $0.122-0.163$ & $8.3-11.3$ \\
\hline $\begin{array}{l}\text { Mount } \\
\text { Manengouba }\end{array}$ & $3.48-5.58$ & $0.58-0.89$ & $6.25-8.77$ & $68-164$ & $0.43-0.76$ & $171-237$ & $0.04-0.10$ & $0.07-0.12$ & \\
\hline Mount Bamenda & $2.85-4.52$ & $0.66-0.88$ & & $84-201$ & $0.46-0.75$ & $124-242$ & $0.06-0.09$ & $0.08-0.12$ & $\ldots \ldots \ldots$ \\
\hline Tombel plain & 4-5.3 & $0.68-0.90$ & $6.2-9.3$ & $68-151$ & $0.34-0.58$ & $145-221$ & $0.056-0.092$ & $0.079-0.125$ & $8.5-12$ \\
\hline Mont Bambouto & 3.1-5 & $0.71-0.94$ & $5.2-14.7$ & $77-271$ & $0.42-0.88$ & $95-275$ & $0.066-0.097$ & $0.07-0.119$ & $6.61-19.37$ \\
\hline $\mathrm{Mt} \mathrm{Oku}$ & $4.39-4.50$ & $0.72-0.75$ & $6.76-9.32$ & $74.51-116.39$ & $0.48-0.52$ & $185.67-197.49$ & $0.08-0.09$ & $0.10-0.13$ & $9.33-12.07$ \\
\hline Bafmeng & $4.91-6.33$ & $0.70-0.99$ & $0.027-4.20$ & $0.34-49.81$ & $0.38-0.49$ & $46.91-70.03$ & $0.07-0.08$ & $0.04-0.09$ & $0.02-5.83$ \\
\hline
\end{tabular}




\section{Conclusion}

The Bafmeng area is characterised by four types of eruptive dynamism in the study area: effusive, extrusive, strombolian and phreatomagmatic dynamism which produce a series of flows domes (basalt) and gentle lava domes (trachyte and rhyolite) and maar products (accretionary lapilli, sags, laminations and beds). The lavas from this area are sodic alkaline series with four distinctive types: ultra-basic type (basanite), intermediate type (benmoreite and trachyte) and acidic type (rhyolite). Geochemically, lavas from the Bafmeng area range from basanite through benmoreite, trachyte to rhyolite. Due to their high $\mathrm{Ni}$, Co and $\mathrm{MgO}$ content, these correspond to primitive or less differentiated rocks and chemistry shows mild contamination. Fractional crystallisation is the principal differentiation mechanism of lava in the area, with ferro-titano oxide, olivine, clinopyroxene and plagioclases being the main fractionation phases. The fractionation of olivine and clinopyroxene is marked by a progressive decrease in the content of $\mathrm{MgO}$ and $\mathrm{CaO}$. The negative anomaly of $\mathrm{Eu}$ in rhyolite indicates fractionation of plagioclase. Discrimination diagrams for distinguishing tectonic environment indicates that studied lava of Bafmeng have within plate volcanic zone geochemical characteristics. The composition of the parental magma is estimated close to the OIB average, but slightly higher values of $\mathrm{Nb} / \mathrm{Ta}$ ratios suggests derivation from distinct liquids although sharing a common source. The magma of the Bafmeng area originated from 1-3\% partial melting of an enriched source and melting took place in the spinel-garnet transition zone. Major and trace element geochemistry of some samples suggest assimilation at different levels, however, a large amount of basanitic melt reach the surface without major contamination. So, complete mixing is unlikely since there is no straight-line relationship in simple binary plot of $\mathrm{K}_{2} \mathrm{O}$ vs $\mathrm{Ba}$ and $\mathrm{Zr}$ vs $\mathrm{MgO}$. The lava of the study area, Mount Bamenda, Mount Oku and Mount Cameroon have the same origin of the magma source, but due to heterogeneity of the asthenospheric mantle, the rocks are formed under different partial melting rates.

\section{COMPETING INTERESTS}

The authors declare that they have no competing interests.

\section{AUTHORS' CONTRIBUTIONS}

M-LVC attended the field trip, interpreted and discussed the volcanological, petrological and geochemical data, read and corrected the manuscript; DGN attended the field trip, interpreted and discussed volcanological, petrological and geochemical data, read and corrected the manuscript; PW attended the field trip, interpreted and discussed volcanological, petrological and geochemical data, read and corrected the manuscript; GDKN attended a field trip, facilitated the thin sections and geochemical analyses, read and corrected the manuscript; IZ contributed on the geochemical interpretation, read and corrected the manuscript; CSG did the thin section study, realized geologic map and other diagrams, read and corrected the manuscript; DTS contributed to the petrography and geochemical interpretation, read and corrected the manuscript.

\section{ACKNOWLEDGEMENTS}

We thank the Geology Laboratories of the Universities of Dschang and Bamenda, and the members of the scientific team of the ALS Laboratory Group, ACME Laboratory, Vancouver, Canada for carrying out our major elements, trace and rare earth elements samples analyses. 


\section{REFERENCES}

Asaah ANE, Yokoyama T, Aka FT, Usui T, Kuritani T, Wirmvem MJ, Ohba T. 2014b. Nature of enriched mantle components beneath the Oku Volcanic Group (OVG) along the Cameroon Volcanic Line (CVL), West Africa. Goldschmidt conference, San Francisco, USA, June 08-13. Abstract No Gold 2014: abs: 1944.

Borghini G, Fumagalli P, Rampone E.2010.The stability of plagioclase in the upper mantle: sub-solidus experiments on fertile and depleted lherzolite. J. Petrol., 51: 229-254.

Burke K. 2001. Origin of the Cameroon line of volcano-capped swells. J. Geol., 109: 349-362.

Fitton JG, Dunlop HM. 1985. The Cameroon line, West Africa and its bearing on the origin of oceanic and continental alkali basalt.Ear.Planet. Sci. lett., 72: 23-38.

Fosso J, Ménard JJ, Bardintzeff JM, Wandji P, Tchoua FM, Bellon H. 2005. Les laves du mont Bangou: une première manifestation volcanique Eocene, à affinité transitionnelle, de la Ligne du Cameroun. C.R. Geosci., 337: 315-325.

Franz G, Steiner G, Volker F, Pudlo D, Hammerschmidt K. 1999. Plume related alkaline magmatism in Central Africathe Meidob hills (W Sudan). Chem. Geol., 157: 27-47.

Frey FA, Green DH, Roy SD. 1978. Integrated models of basalt petrogenesis: a study of quartz tholeiites to olivine melilitites from South Eastern Australia utilizing geochemical and experimental petrological data. J. Petrol., 19: 463e 513.

Girod M, Dautria JM, Giovanni RD. 1987. A first insight into the constitution of the upper mantle under the Hoggar area (Southern Algeria): the lherzolite xenoliths in the alkali-basalts. Mantle xenoliths.C.R. Acad. Sci., 77: 66-73.

Halliday AN, Dickin AP, Fallick AE, Fitton JG. 1988. Mantle dynamics: aNd, $\mathrm{Sr}, \mathrm{Pb}$ and $\mathrm{O}$ isotopics study of the Cameroon line volcanic chain. J. Petrol., 29: 181211.

Halliday AN, Davidson JP, Holden P, Dewolf C, Lee DC, Fitton JG. 1990. Traceelement fractionation in plumes and the originof HIMU mantle beneath the Cameroon Line. Nature, 347: 523-528.

Kamgang P, Njonfang E, Nono A, Gountie D, Tchoua MF. 2010. Petrogenesis of a silicic magma system: Geochemical evidence from Bamenda Mountains, NW Cameroon, Cameroon Volcanic Line. $J$. Afr.Ear. Sci., 58: 285-304.

Kamgang P, Chazot C, Njonfang E, Njongang NB, Tchoua MF. 2013. Mantle sources and magma evolution beneath the Cameroon Volcanic line: geochemistry of mafic rocks from the Bamenda Mountains (NW Cameroon). Gondw. Res., 24: 727-741.

Kampunzu AB, Popoff M. 1991. Distribution of the main Phanerozoic African rifts and associated magmatism, introductory notes. In Magmatism in Extensional Structural Settings. The Phanerozoic African plate, Kampunzu AB, Lubala R (eds). Springer: Berlin, New York, Heidelberg; 2-10.

Kuepouo G, Tchouankoue JP, Nagao T, Sato H. 2006. Transitional tholeiitic basalts in the Tertiary Bana volcano-plutonic complex, Cameroon Line. J. Afr. Ear. Sci., 45: 318-332.

Lee DC, Halliday AN, Fitton JG, Poli G. 1994. Isotopic variations with distance and time in the volcanic islands of the Cameroon Line: evidence for a mantle plume origin. Ear. Planet. Sci. Lett., 123: 119-138. 
Le Maitre RW. 2002. Igneous Rocks: A Classification and Glossary of Terms (2nd edn). Cambridge Press.

Lissom J. 1991. Etude pétrologique des laves alcalines du massif d'Oku: un ensemble volcanique de la "ligne du Cameroun". Th. Univ. Paris VI, Paris, p.207.

McDonough WF. 2003. Compositional models for Earth's core. In the Mantle and Core (vol.2), Carlson RW (ed). Treatise on Geochemistry, Holand HD and Turekian KK (ed). Elsevier-pergamon: Oxford; $547-568$

McDonough WF, Sun SS. 1995. The composition of the earth. Chem. Geol., 120: $223-253$.

Middlemost EAK. 1975. The basalt clan. Ear. Sci. Rev., 11: 337-364.

Moundi A, Wandji P, Bardintzeff JM, Menard JJ, OkomoAtouba LC, Mouncherou OF, Reusser E, Bellon H, Tchoua FM. 2007. Les basaltes éocènes à affinité transitionnelle $\mathrm{du}$ plateau Bamoun, témoin d'un réservoir mantellique enrichi sous la ligne du Cameroun. C. R. Géosci., 339: 396-406.

Ngounouno I, Deruelle D, Demaiffe D. 2000. Petrology of the bimodal Cenozoic volcanism of the Kapsiki Plateau (Northernmost Cameroon, Central Africa). J. Volc. Geotherm. Res., 102: 2144.

Ngounouno I, Déruelle B, Guiraud R, Vicat JP. 2001. Magmatismes tholéiitique et alcalin des demi-grabens crétacés de Mayo OuloLéré etde Babouri-Figuil (Nord du Cameroun-Sud du Tchad) en domaine d'extension continentale. C. R. Acad. Sci., 333: 201-207.

Njilah I. 1991.Volcanology and Geochemistry of the Oku massifs in Cameroon. 15 colloquium of African Geology, Abstract 1990/20, p. 138.
Njilah K, Robert T, Charles R, Nzolang C, Rose T, Humphrey A. 2007. Geochemistry of Tertiary-Quaternary lavas of Mount Oku, Northwest Cameroon. Revista Facultad de Ingeniera, 40: 59-75.

Njonfang E, Nono A, Kamgang P, Ngako V, Tchoua FM. 2011. Cameroon line magmatism (Central Africa): a reappraisal Beccaluva L, Bianchini G, Wilson M(ed), Volcanism and Evolution of the African Lithosphere. GSA, Special Paper, 478:173-191.

Nkouathio DG, Kagou DA, Bardintzeff JM, Wandji P, Bellon $\mathrm{H}$, Pouclet A. 2008. Evolution of volcanism in graben and horst along the Cenozoic Cameroon Line (Africa): implication for tectonic evolution and mantle source composition. Min. Petrol., 94(3-4): 287-303.

N'Ni J. 1984. Le volcan actif du Mont Cameroun (Ligne du Cameroun): géologie et pétrologie du volcan. Th. $3^{\mathrm{e}} \mathrm{C}$., Univ. Paris-Sud XI, Orsay, France, p.257.

Pfänder JA, Münker C, Stracke A, Mezger K. 2007. $\mathrm{Nb} / \mathrm{Ta}$ and $\mathrm{Zr} / \mathrm{Hf}$ in ocean island basalts - implications for crust-mantle differentiation and the fate of niobium. Ear.Planet. Sci. Lett., 254:158-172.

Pouclet A, Kagou Dongmo A, Bardintzeff JM, Wandji P, Chakam Tagheu P, Nkouathio D, Bellon H, Ruffet G. 2014.The Mount Manengouba, a complex volcano of the Cameroon Line: volcanic history, petrological and geochemical features. $J$. Afr. Ear. Sc., 97:297-321.

Rampone E, Hofmann AW, Piccardo GB, Vannucci R, Bottazzi P, Ottolini L.1995. Petrology, mineral and isotope geochemistry of the External Ligurideperidotites (Northern Appennine, Italy). J. Petrol., 36: 61-76.

Saunders AD, Norry MJ, Tarney J. 1988. Origin of MORB and chemically- 
depleted mantle reservoirs: trace element constrains. J. Petrol. Special Lithosphere Issue: $415-445$.

Schandl ES, Gorton MP. 2002. Applications of high field strength elements to discriminate tectonic setting in VMS environments. Econ. geol., 97: 629-642.

Schilling M, Conceição RV, Mallmann G, Koester E, Kawashita K, Hervé F, Morata D, Motoki A. 2005. Spinel-facies mantle xenoliths from Cerro Redondo, Argentine Patagonia: Petrographic, geochemical, and isotopic evidence of interaction between xenoliths and host basalt. Lithos, 82:485-502.

Sun SS, McDonough WF. 1989. Chemical and isotopic systematics of oceanic basalts: implications for mantle composition and processes. In: Saunders AD, Norry MJ. (edn), Magmatism in the Ocean Basins. Geological Society of London Special Publication, 42: 313-345.

Tamen J, Nkoumbou C, Eric R, Tchoua MF. 2015. Petrology and geochemistry of mantle xenoliths from kapsiki Plateau (Cameroon Volcanic Line): implications for lithospheric upwelling. J. Afr. Ear. Sci., 101: 119134.Doi:10.1016/j.jafrearsci.2014.09.008 Tsafack JPF, Wandji P, Bardintzeff JM, Bellon H, Guillou H. 2009. The Mount Cameroon stratovolcano (Cameroon Volcanic Line, Central Africa): Petrology, geochemistry, isotope and age data. Geochem. Miner. Petrol., 47: 65-78.

WandjiP, Tchokona SD, Bardintzeff JM, Bellon H, Platevoet B. 2008. Rhyolite of the Mbèpit Massif in the Cameroon
Volcanic Line: an early extrusive volcanic episode of Eocene age. Miner. Petrol., 94: 271-286.

Wandji P, Tsafack JPF, Bardintzeff JM, Nkouathio DG, Kagou Dongmo A, Bellon H, Guillou H. 2009. Xenoliths of dunites, wehrlites and clinopyroxenites in the basanites from Batoke volcanic cone (Mount Cameroon, Central Africa): petrogenetic implications. Miner. Petrol., 96: 81-98. Doi: 10.1007/s00710-0080040-3.

Weaver BL. 1991. The origin of ocean island basalt end-member compositions: trace element and isotopic constraints. Ear. Planet. Sci. Lett., 104: 381-397.

Wotchoko P, Tene Djoukam JF, Kouankap Nono GD, Kouske PA, Nkouathio DG, Atenkia Fonkem S. 2015. Petrographic and geochemical characterization of basalts in Bangangte area (West Cameroon): implications on their source. Ear. Sci., 4(6): 266-274. Doi:10.11648/j.earth.20150406.18.

Wotchoko P, Nkouathio DG, Kouankap NGD, Chenyi MLV, Guedjeo CS, Bulam AT, Tchokona SD, Seplong Y. 2016. Petrogenesis of lava from Wainama West, Mount Oku (CVL): source characterization and magma evolution. $J$. Geosci. Geom., 4(4): 91-101. Doi: 10.12691/jgg-4-4-3.

Zhang JJ, Zeng YF, Zhao ZF. 2009. Geochemical evidence for interaction between oceanic crust and lithospheric mantle in the origin of Cenozoic continental basalt in east central China. Lithos, 110: 305-326. 